\title{
Individualism and Venture Capital: A Cross-Country Study
}

\author{
Pascal Gantenbein ${ }^{1} \cdot$ Axel Kind $^{2} \cdot$ Christophe Volonté ${ }^{1,2}$ (D)
}

Received: 9 February 2018 / Revised: 29 May 2019 / Accepted: 19 June 2019 / Published online: 16 July 2019 (c) The Author(s) 2019

\begin{abstract}
We investigate the effect of individualism - a dimension of culture that is strongly associated with entrepreneurship —on venture-capital investments using a large cross-country sample. Our sample consists of 1496 country-year observations and includes 88 countries from 1998 to 2014. Controlling for economic conditions, the legal environment, and different aspects of culture, we find that individualism is positively and significantly related to venture-capital investments and explains $30 \%$ of cross-country variation. This result is stable across different subsamples, several measures of venture-capital investments, and even holds when using the political system 200 years ago as an instrument for individualism. The quality of formal institutions (rule of law) and entrepreneurial attitudes (uncertainty avoidance) partially mediate the effect of individualism on venture-capital investments, while economic conditions (GDP per capita) moderate this effect.
\end{abstract}

Keywords Comparative entrepreneurship · Cultural values · Individualism · Institutions · Venture capital

\section{Introduction}

The success of the US Silicon Valley is often reported to stem from the American spirit of entrepreneurship, people's risk appetite, and their capitalistic mentality. These factors are usually recognized to provide an ideal breeding ground for the launch of start-ups and the provision of venture capital (see The Economist 2009). According to several authors (see, e.g., Gompers and Lerner 2001; Jeng and Wells 2000; Kortum and Lerner 2000; Popov and Roosenboom 2013; Samila and Sorenson 2011), start-ups are fundamental for innovation and productivity, the renewal of economies, the creation of jobs, and economic growth. In line with this view, the G20 leaders concluded in their 2014 Summit that the "promotion of competition,

Christophe Volonté

christophe.volonte@unibas.ch

1 Faculty of Business and Economics, University of Basel, Basel, Switzerland

2 Department of Economics, University of Konstanz, Konstanz, Germany 
entrepreneurship and innovation' would help increasing economic growth. Given the importance of venture capital for economic development, researchers have put considerable efforts in explaining different drivers of venture-capital investments. In particular, scholars were able to show that different formal institutions matter for the development of venture-capital markets. ${ }^{1}$

In spite of these findings, the academic community still struggles in explaining the large differences in venture-capital investments across countries (see, e.g., Wright et al. 2005). In particular, although cultural aspects are recognized to affect economic outcomes in a variety of situations and dimensions (see, e.g., Franke et al. 1991; Li et al. 2011) and Fukuyama (1995, p. 103) has argued that "[...] nonrational factors like culture, religion, tradition, and other pre-modern sources, will be key to the success of modern societies in a global economy", no study has so far studied the direct influence of individualism - a cultural trait that emphasizes individual freedom, personal responsibility, self-reward, self-orientation, as well as personal achievement and fulfillment—on venture-capital investments. This research gap is surprising, as Gorodnichenko and Roland (2012) and Heine (2008) convincingly argue that individualism is the most important aspect in cross-cultural psychology and represents the main cultural divide in today's world.

In this paper, we address this research gap by studying the influence of individualism on venture-capital investments across countries and considering both moderating and mediating variables of this relationship. On the theoretical side, we argue that individualism encompasses entrepreneurial characteristics and thus fosters venture-capital investments. Furthermore, individualism is also positively related with the quality of formal institutions (e.g., rule of law) and informal institutions (e.g., generalized trust) that both support venture-capital activity. In this respect, the paper builds on the insights from new institutional theorists, such as North (1990). Figure 1 summarizes the structure of our analysis by depicting these relationships and highlighting the positioning of the paper.

On the empirical side, we perform an extensive empirical analysis on a sample of 1496 country-year observations based on ca. 300,000 venture-capital transactions across 88 countries over the period 1998-2014. We show that individualism accounts for $30 \%$ of cross-country variation in venture-capital investments, which makes it the single most important variable in terms of cross-country explanatory power. Furthermore, we show that even after accounting for a large set of controls, moderating variables, suitable mediating variables, and endogeneity issues, the direct effect of individualism on venture-capital investments persists both statistically and economically. Finally, based on an extensive analysis of moderating and mediating effects, we offer evidence that the influence of individualism on venturecapital investments is moderated by economic conditions (GDP per capita) and

\footnotetext{
${ }^{1}$ Armour and Cumming (2006) focus on the importance of the political and legal framework; Black and Gilson (1998) underline the relevance of financial-markets development; Da Rin et al. (2006) stress the importance of the tax system; and Jeng and Wells (2000) find evidence for the significance of labormarket regulations. Lerner and Tag (2013) show, among other things, the importance of public spending for R\&D investments and its value for venture-capital activities.
} 


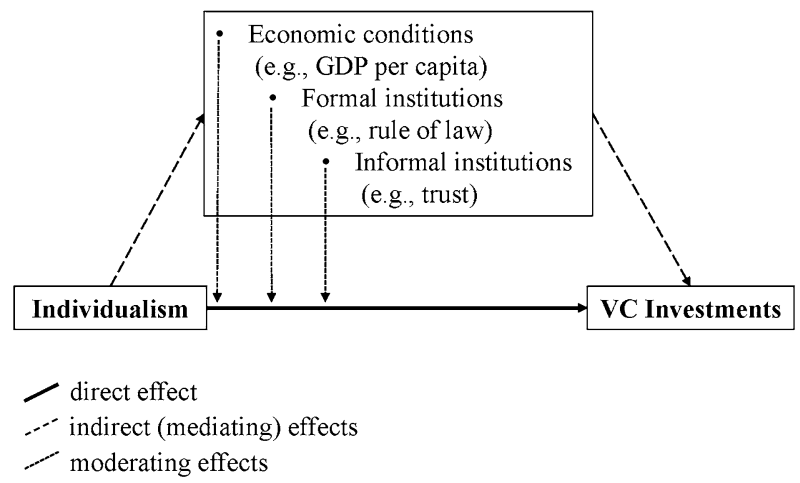

Fig. 1 Theoretical model on the relationship between individualism and venture-capital investments

partially mediated by the quality of formal institutions (rule of law) and entrepreneurial attitudes (uncertainty avoidance).

Our study contributes in several ways to different strains of literature. First, we contribute to the growing literature that links culture to economic outcomes and decisions (see, e.g., Chen et al. 2015; Guiso et al. 2003, 2006, 2009; Li et al. 2011). Second, we add to the current debate on the relative importance of individualism within the broader spectrum of culture [see, e.g., Gorodnichenko and Roland 2012; Heine 2008; Hofstede et al. 2010 (HHM)]. Third, and most importantly, our study contributes to the ongoing discussion on the determinants of venture-capital markets (see, e.g., Armour and Cumming 2006; Jeng and Wells 2000; Lerner and Tag 2013; Li et al. 2014) by establishing, for the first time, a direct relationship between individualism and venture-capital investments across countries. In contrast to $\mathrm{Li}$ and Zahra (2012) — who suggest that culture moderates the effect of formal institutions on venture-capital investments - we show that individualism is the single most important cultural element in explaining venture-capital investments. Fourth, as institutional theorists argue that institutions (formal and informal) affect economic outcomes both directly and indirectly (North 1990, 1994; Scott 1995; Williamson 2000), we contribute to the understanding of these issues by providing an extensive analysis of the moderating and mediating effects in the relationship between individualism and venture-capital investments.

The sample of 88 countries employed in this paper is larger than the samples used in existing studies on the determinants of cross-country venture-capital investments (e.g., Anokhin and Schulze 2009: 64 countries; Da Rin et al. 2006: 14 countries; Jeng and Wells 2000: 21 countries; Li and Zahra 2012: 68 countries). As our sample includes both developed countries and emerging markets, we are able to capture a larger variety of manifestations of individualism as well as economic and institutional conditions.

In the paper, we specifically address the recommendations of Kirkman et al. (2006), as elaborated in Beugelsdijk et al. (2017) on HHM-inspired work. First, we make sure to establish a clear distinction between country and culture by controlling for a large set of country-specific characteristics beside culture, such as economic 
conditions (e.g., GDP growth, GDP per capita, and exports), geographic conditions (e.g., latitude and malaria infections), and the formal institutional environment (e.g., the legal system). The relationship is robust to the inclusion of all the above controls and holds for different subsamples (e.g., different income groups and time subperiods).

Second, we consider and explore cultural values beyond those proposed in HHM by including cultural characteristics, such as religion, language, and World Value Survey's trust in the regressions.

Third, throughout the paper, we stress not only the statistical significance of the influence of individualism on venture-capital investments but also its economics significance in terms of magnitude and explanatory power.

Finally, we address endogeneity concerns by using an instrumental variable (IV) approach that confirms the main findings. Our instrument (polity score) measures the characteristics of a country's political system between the Congress of Vienna (1815) and just before the outbreak of World War I (1914), i.e., within the period 1816-1913. As this period was relatively stable, it likely laid ground to the values and norms that define individualism in modern societies. We provide evidence that the polity score is a valid instrument as it is related with individualism but is uncorrelated with venture-capital investments.

\section{Theoretical Framework}

\subsection{Venture Capital}

The prosperity of economies depends on the commercialization of ideas. The transformation from innovative ideas into new products often originates from start-ups (see Kortum and Lerner 2000) that require financial resources in the form of venture capital (see, e.g., Jeng and Wells 2000). In this respect, the definition of venture capital used in this paper is broad and includes all types of equity financing provided to young companies by a variety of investors, such as family members, friends, and 'fools' (3F-Hypothesis), business angels, foundations, pension funds, or venture-capital funds. On the contrary, start-ups cannot typically rely on either internal financing or external debt, because they lack both (stable) cash flows and tangible assets to be pledged as collateral.

Unfortunately, venture-capital financing tends to be scarce for several reasons. First, it is intrinsically risky due to the large number of potential pitfalls that can jeopardize a steady growth path of start-ups and which ultimately results in very high failure rates (Cochrane 1981; Stinchcombe 1965). Second, venture-capital investments are characterized by a material asymmetric distribution of information (also due to a relatively low level of transparency) and serious conflict of interests between investors and start-up founders (see Amit et al. 1998; Jensen and Meckling 1976; Sahlman 1990). In particular, venture-capital investors often have to overcome an information disadvantage with respect to the technology, the founders' skills, and their commitment. Further, the entrepreneurs are often emotionally bounded to the firm, whereas the venture capitalists mainly focus on the return on investment. 
The entrepreneurs' creativity and innovations are key drivers of economic development. While lasting peace or open economies are basic conditions for economic growth and good laws can act as a transmitter, Cooter and Schäfer (2012) point out that the economic development of a country affects the provision of (non-relational) venture capital. Several studies show that the countries' (formal) institutional environment, e.g., their political and legal framework (see Armour and Cumming 2006), financial-markets development (see Black and Gilson 1998), tax system (see Da Rin et al. 2006), labor-market regulations (see Jeng and Wells 2000), and public spending on R\&D, correlates with venture-capital activities (see Lerner and Tag 2013). For instance, the financial risk investors are facing can be mitigated through tax-system provisions that favor risky start-up investments (e.g., by granting tax-loss carryforwards over several years). Especially in developed countries with their saturated economies, new ideas enhance productivity and therefore economic growth. For this reason, in the last decades, governments around the World have aimed at fostering entrepreneurial activity. In particular, they have improved the legal environment (e.g., by the Small Business Act for Europe, a framework for the EU policy on Small and Medium Enterprises (SMEs) introduced in 2008), promoted the exchange between universities and business, and created so called techno parks for hosting start-ups (see, e.g., Haufler et al. 2014; Markman et al. 2008). However, there are still significant differences in venture-capital investments across countries that raise fundamental questions on these governmental initiatives.

\subsection{Culture}

New institutional theorists, such as North (1990, 1994), argue that the 'rules of the game' according to which individuals and organizations interact consist of both formal institutions (e.g., regulations or law enforcement) and informal institutions (e.g., culture). In the economics literature, culture has been argued to affect economic outcomes in a variety of situations and dimensions. ${ }^{2}$ Fukuyama (1995, p. 103) states that "non-rational factors like culture, religion, tradition, and other premodern sources, will be key to the success of modern societies in a global economy". According to Hofstede (1980) and Schwartz (1999), culture comprises shared values, norms, beliefs, and practices within a society that change only slowly from one generation to the next. In the case of venture capital, both entrepreneurs' willingness to start an enterprise and investors' propensity to invest in risky projects may depend on their cultural heritage (see, e.g., Bruton et al. 2005; De Clercq et al.

\footnotetext{
2 Economic growth (Franke et al. 1991), economic development (Glahe and Vohries 1989), financial development (Beck et al. 2003), financial intermediation (Aggarwal and Goodell 2010), foreign direct investment (Guiso et al. 2009; Siegel et al. 2013), government quality (La Porta et al. 1999), international capital flows (Siegel et al. 2011), board of directors (Volonté 2015) and ownership structure (Holderness 2017), pension systems (Aggarwal and Goodell 2013), leverage (Li et al. 2011), cash holdings (Chen et al. 2015), mergers and acquisitions (Ahern et al. 2015; Frijns et al. 2013; Stahl and Voigt 2008), financial contracts (Giannetti and Yafeh 2012), and cross-country venture capital flows (Bottazzi et al. 2016; Dai et al. 2012; Li et al. 2014; Nahata et al. 2014).
} 
2012). Hofstede et al. (2010) (HHM) describe a nation's culture along six dimensions $^{3}$ that stem from people's values and preferences within a country. As documented in the excellent review articles of Beugelsdijk et al. (2017) and Kirkman et al. (2006), HHM's work has triggered an extraordinary fruitful avenue of research in the field of international business and management to which we would like to contribute with this paper.

\subsection{Individualism}

Hofstede (1980) defines individualism as a "preference for a loosely-knit social framework in which individuals are expected to take care of only themselves and their immediate families". Individualism emphasizes individual freedom, personal responsibility, self-reward, and self-orientation. In this paper, we argue that the effect of individualism on venture-capital investments is positive because of the following reasons.

First, and most importantly, individualism fosters the entrepreneurial attitude as it is closely related to pro-market attitudes, risk-taking, entrepreneurship, and innovation (see, e.g., Ang 2015; Chui et al. 2010; Li et al. 2013; Morris et al. 1994; Shane 1992, 1993; Shao et al. 2013; Taylor and Wilson 2012; Tiessen 1997; Yamagishi et al. 1998; Yamagishi and Yamagishi 1994). For this reason, the feature of a very high level of individualism in the American culture may very well be one reason for the extraordinary success of venture capitalism in the US. In contrast, collectivism characterizes societies in which group affiliation (families, clans, personal relations, networks, and loyalty) and in-group thinking are important, and forms of nepotism may occur. Such an 'insider'-system is rather counterproductive for innovative and 'out-of-the-box' ideas which often accompany start-ups.

Second, a higher level of individualism within a country is also associated with conditions that favor venture-capital investments. For example, Han et al. (2010) and Zhang et al. (2013) show that individualism is related to investor protection and thereby increases the willingness to provide capital to start-ups (see also Lerner and Schoar 2005). Individualism also improves accountability and transparency (Griffin et al. 2014), which, in turn, decreases the information asymmetry between the entrepreneur and the venture capitalist, reduces capital costs, and fosters venture-capital investments. Finally, empirical evidence also suggests that individualism leads to better corporate governance (Haxhi and van Ees 2010) and thus reduces agency costs arising from conflict of interests between the venture capitalist (the principal) and the entrepreneur (the agent).

Third, several researchers also argue that individualism is positively related to generalized trust (e.g., Allik and Realo 2004; Huff and Kelley 2003, 2005; Realo et al. 2008; Yamagishi et al. 1998; Yamagishi and Yamagishi 1994). In contrast

\footnotetext{
${ }^{3}$ Hofstede/HHM's (1980, 2010) six dimensions of culture include, beside individualism-collectivism, power distance, uncertainty avoidance, masculinity-femininity, long-term orientation, and indulgence.
} 
to particularized trust, generalized trust refers to the interpersonal relationships between people outside their group, which turns out to be particularly important for economic transactions (Banfield 1958). ${ }^{4,5}$ Generalized trust has been argued to affect economic outcomes, such as trade, growth, cross-border investments, development of stock markets, and overall economic activity (see, e.g., Algan and Cahuc 2010; Ang et al. 2015; Franks and Mayer 2017; Guiso et al. 2009; Sapienza and Zingales 2012). ${ }^{6}$ Individualistic societies (e.g., European and Anglo-Saxon countries, such as the United States, Australia, the United Kingdom, and Canada) with the exception of China (Bjornskov 2007; Steinhardt 2012) exhibit higher levels of generalized trust than collectivistic societies (e.g., countries in Asia, Africa or Latin America). Trust reduces transaction costs in principal-agent situations (Nannestad 2008; Williamson 1975) and, therefore, potentially fosters venture-capital investments (see, e.g., Bottazzi et al. 2016; Duffner et al. 2009; Fairchild 2011). Further, Kwon and Arenius (2010) find that generalized trust (or social capital) increases the perception of entrepreneurial opportunities and that investors in countries with higher generalized trust are more likely to invest in entrepreneurs with whom they have only weak personal ties. Our hypothesis is therefore stated as follows.

Hypothesis: Individualism is positively related to venture-capital investments.

\section{Data and Definition of Variables}

We consider all venture-capital transactions between 1998 and 2014 included in the Thomson ONE Banker's database. Thomson ONE Banker is an established source for studies on venture capital (see, e.g., Dai et al. 2012; Espenlaub et al. 2015; Gompers et al. 2008; Guler and Guillén 2010; Li et al. 2014). Its private equity module (formerly VentureXpert) integrates data from Thomson Venture Economics and Thomson Macdonald.

The sample covers over 300,000 venture capital transactions conducted in 148 countries between 1998 and 2014, which corresponds to 2516 country-year observations. By requiring all countries to have at least one entry, we make sure that the

\footnotetext{
${ }^{4}$ Generalized trust describes the general level of (moralistic) trust within a society and refers to trust toward strangers and not toward known people. In contrast, particularized trust can be seen as trust established between known people and thus involves significant amounts of time for its creation. For the impact of trust on economic activity and investments within a country, the concept of generalized trust has thus to be the reference.

${ }^{5}$ Lacking social capital (i.e., particularized trust dominating generalized trust) has been brought forward as a reason of Southern Italy's relative poverty by Putnam et al. (1993).

${ }^{6}$ Houser et al. (2010) differentiate between trust decisions and risky decisions by arguing that trust decisions occur in principal-agent-relationships where one party's decision affects another's outcome, while risky decisions occur where the outcome is determined by statistical conditions (see also Bohnet and Zeckhauser 2004; Eckel and Wilson 2004). Similarly, Knight (1921) distinguishes between risk and uncertainty. Risk (and risk aversion) is related to objective interpretations of (statistical) probabilities ('measurable uncertainty') which are calculable, while uncertainty is related to subjective interpretations of probabilities ('unmeasurable uncertainty') which are based on human beliefs.
} 
Table 1 Sample construction

\begin{tabular}{lc} 
Number of countries according to United Nations & 193 \\
Number of countries without any venture capital transaction according to Thomson ONE Banker & 45 \\
Venture capital sample & 148 \\
Number of countries not covered by World Bank or with missing values & 11 \\
Number of countries without scores on Individualism & 49 \\
Number of countries in final sample & 88 \\
\hline
\end{tabular}

countries considered are screened by Thomson Reuters with respect to venture-capital investments. We match this data with information about the countries' cultural, economic, and institutional characteristics as provided by Hofstede's homepage (geert-hofstede.com), CIA's World Fact Book, and the World Bank. Due to missing values, we must exclude 60 countries, which leaves us with a final base sample of 88 countries and 1496 country-year observations (see Table 1).

\subsection{Venture-Capital Investments}

The dependent variable of this study is venture capital. It measures the total amount of risk capital received by young companies in a given country during a given year. This amount includes all investments in seed, early-stage, expansion, or later-stage start-ups that are classified as venture capital in Thomson ONE Banker. In consequence, it includes all private-equity transactions except leverage buyouts. Thereby, financing is provided from various economic actors: individuals, business angels, corporations, governments, pension funds, and venture-capital funds. ${ }^{7}$ Figure 2 depicts the cross-sectional variation of total venture-capital investments around the World.

\subsection{Individualism}

We use data on individualism from Geert Hofstede's homepage on culture (http://geert-hofstede.com). Individualism can take values from 0 to 100 . Countries with scores below 50 are considered 'collectivist' and those with scores above 50 are considered 'individualist'.

\footnotetext{
7 Thomson ONE Banker collects data on venture-capital investments and categorizes them-in dependence of the providing actor/institution-into the following groups: "Angel Group", "Bank Affiliated", "Corporate PE/Venture", "Endowment, Foundation or Pension Fund", "Government Affiliated Program", "Incubator/Development Program", "Individuals", "Insurance Firm Affiliate", "Investment Management Firm", "Non-Private Equity", "Other", "Private Equity Advisor or Fund of Funds", "Private Equity Firm", "SBIC" (Small Business Investment Company), "Service Provider" and "University Program".
} 


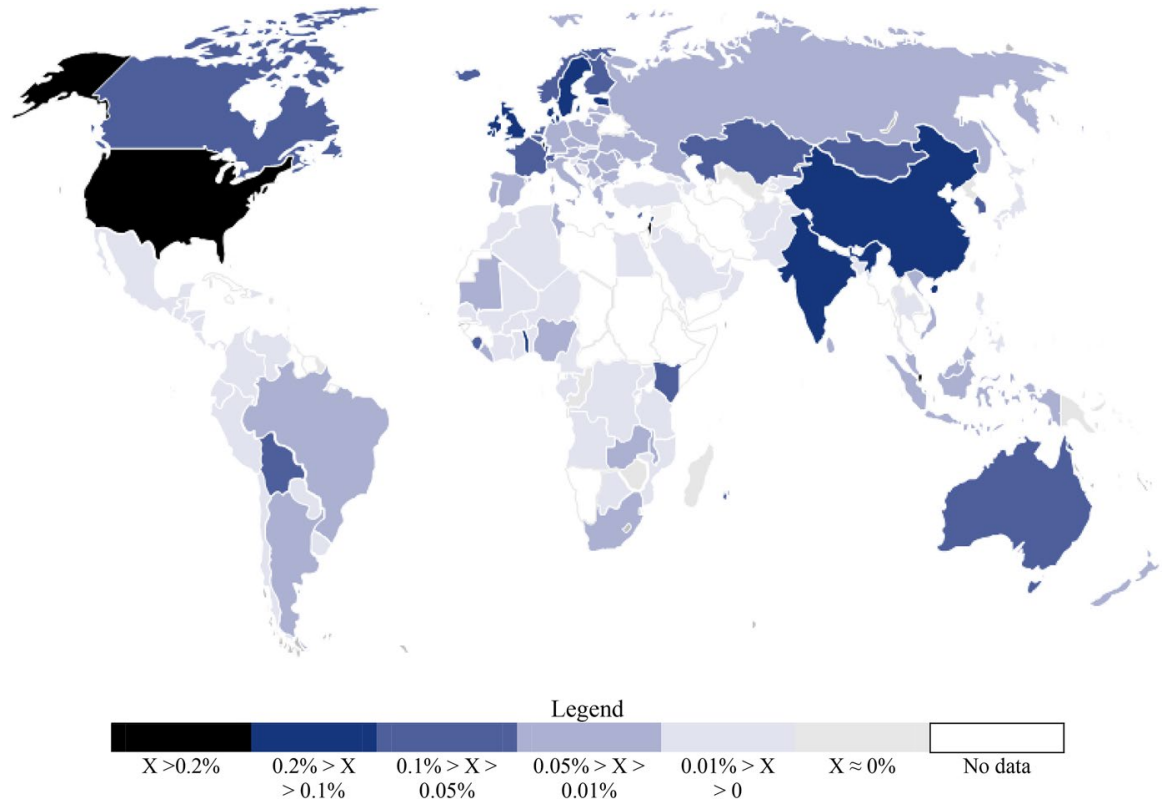

Fig. 2 Venture capital world map (venture capital/GDP, X, Ø 1998-2014)

\subsection{Control Variables}

We account for several country characteristics that may affect venture-capital investments. GDP growth is computed as the one-year lagged annual change in Gross Domestic Product (GDP). We control for this variable because Jeng and Wells (2000), among others, argue that growing countries create more investing opportunities. GDP per capita is the GDP scaled by the population. Rule of law measures the quality of contract enforcement, property rights, police, and courts, as well as the likelihood of crime and violence. This variable stems from the Worldwide Governance Indicators (WGI) project. A stronger rule of law should increase the willingness of investors to provide money to start-ups. Exports is the percentage of exports of goods and services to GDP. Population growth is computed as the annual population growth rate lagged by one year. GDP is the Gross Domestic Product in US Dollars and is an indicator for a country's economic importance and size. Definitions of baseline variables and summary statistics are provided in Tables 2 and 3, respectively.

Table 4 shows the correlation matrix among all variables used in the baseline regressions. 


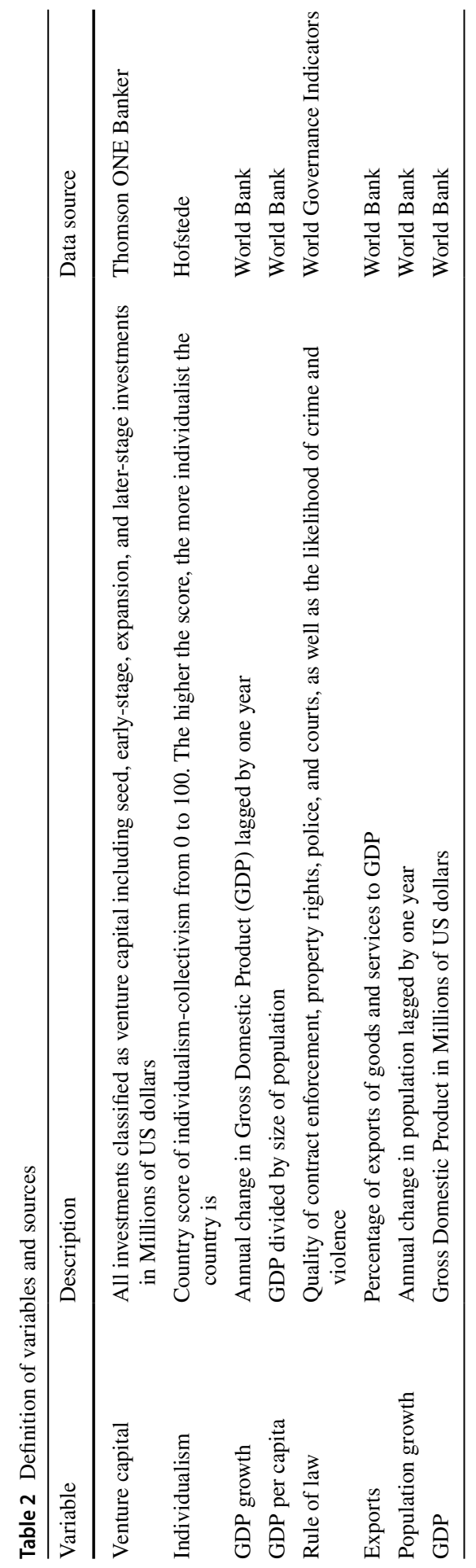


Table 3 Summary statistics

\begin{tabular}{llllll}
\hline & Mean & Median & Min & Max & SD \\
\hline Venture capital (M\$) & 577 & 4 & 0 & 106,900 & 4299 \\
Individualism & 40.2 & 32.5 & 6.0 & 91.0 & 22.9 \\
GDP growth (in \%) & 3.7 & 3.8 & -14.8 & 33.7 & 3.9 \\
GDP per capita & 16,410 & 7694 & 148 & 116,700 & 19,396 \\
Rule of law & 0.33 & 0.17 & -1.89 & 2.12 & 1.00 \\
Exports (in \% of GDP) & 43.96 & 34.54 & 7.03 & 230.30 & 33.70 \\
Population growth (in \%) & 1.2 & 1.1 & -4.9 & 17.3 & 1.5 \\
GDP (M\$) & 571,700 & 117,800 & 636 & $17,350,000$ & $1,655,279$ \\
\hline
\end{tabular}

Summary statistics of the variables. The sample consists of 1496 country-year observations from 1998 to 2014. The table presents mean, median, minimum (Min), and maximum (Max) values as well as standard deviation (SD) for each variable

\section{Methodology and Empirical Results}

Individualism has been associated with entrepreneurial spirit. We estimate the following regression model to test the hypotheses about the effect of individualism on venture-capital investments:

$$
{\text { venture } \text { capital }_{i, t}=\alpha+\beta_{1} \cdot \text { individualism }_{i, t}+\delta \cdot \text { controls }_{i, t}+\varepsilon_{i, t}} \text {, }
$$

where venture capital is the total amount of venture-capital investments of country $i$ in year $t$. Many countries have no venture-capital transactions in some years, therefore the distribution of our main dependent variable, venture capital, is strongly right-skewed. For this reason, we log transform it. We run pooled regressions with cluster-robust standard errors because errors are likely to be correlated within countries. As our focus variable, individualism, is time invariant, we are not able to use country fixed effects which would account for unobserved (and time-invariant) national characteristics.

\subsection{Baseline Model}

The regression results of our baseline model provide first empirical evidence that individualism is positively related to venture capital (Table 5, column II). Importantly, the variance inflator factors never exceed 5, which indicates that multicollinearity is not a serious issue for our regression results. In addition, the regression in column III indicates that individualism explains one third of the variation of venture-capital investments across countries. Conversely, only two thirds of the variation of venture capital around the world are not explained by this single variable.

This relationship is also depicted in Fig. 3: in panel (a) for the total sample and in panel (b) and panel (c) for high- and low-income countries, respectively. 


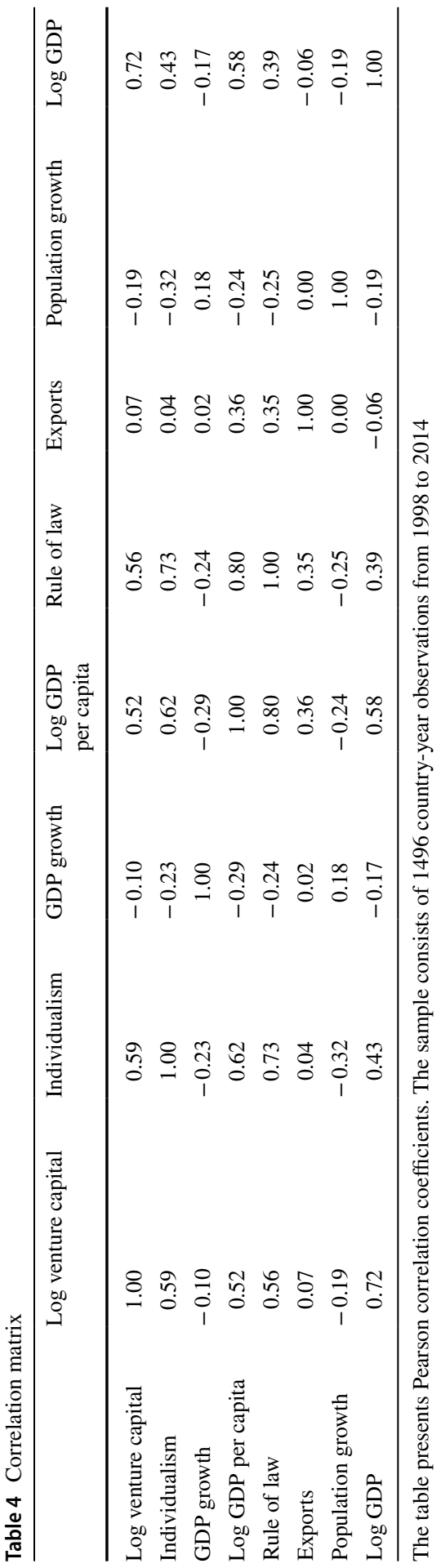


Table 5 Individualism and venture-capital investments

Log venture capital

(I)

(II)

(III)

\begin{tabular}{llll}
\hline Intercept $)$ & $-3.53814 * * *(0.785)$ & $-7.01906^{* * *}(1.060)$ & $-0.18940(0.379)$ \\
Individualism & & $0.02745^{* * *}(0.007)$ & $0.06617 * * *(0.009)$ \\
GDP growth & $0.00187(0.012)$ & $0.03139^{*}(0.019)$ & \\
Log GDP per capita & $-0.35381^{* * *}(0.127)$ & $-0.47998^{* * *}(0.128)$ & \\
Rule of law & $1.10858^{* * *}(0.139)$ & $0.85768^{* * *}(0.163)$ & \\
Exports & $0.00133(0.003)$ & $0.00787^{* *}(0.003)$ & \\
Population growth & $-0.04141(0.039)$ & $0.04807(0.060)$ & \\
Log GDP & $0.76758^{* * *}(0.087)$ & $1.02060^{* * *}(0.098)$ & \\
Years & Included & Included & Excluded \\
Number of observations & 2329 & 1496 & 1513 \\
$\mathrm{R}^{2}$ & 0.629 & 0.689 & 0.330 \\
Adj. $\mathrm{R}^{2}$ & 0.623 & 0.678 & 0.330 \\
$F$-statistic & $177.8^{* * *}$ & $141.6^{* * *}$ & $745.4 * * *$
\end{tabular}

The table presents regression coefficient estimates for individualism. The sample consists of 2329, 1496, and 1513 country-year observations respectively from 1998 to 2014. Cluster-robust standard errors are reported in parentheses. Significance at $1 \%, 5 \%$, and $10 \%$ levels is indicated by $* * *, * *$, and $*$, respectively

\subsection{Additional Economic Control Variables}

As individualism may also affect other economic and institutional factors which in turn may influence venture-capital investments, we include a battery of additional control variables in the next step. All the data is provided by the World Bank. Unemployment is the percentage of labor force without jobs and is lagged by one year. A higher rate of unemployment may increase the pool of (necessity-based) entrepreneurs. Market capitalization/GDP is market capitalization of listed companies in a country divided by GDP and lagged by one year. It is used as a proxy for the development of financial markets and the venture capitalists' opportunities to exit their investment via an IPO, which increases their willingness to invest in the first place (see Black and Gilson 1998; Jeng and Wells 2000; Nahata et al. 2014). Foreign direct investments is the ratio of foreign direct investment net inflows (FDI) to GDP. It measures a countries' openness to foreign capital (see Kim and Lu 2013; Nahata et al. 2014). Trade is the ratio of the sum of exports and imports to GDP. Real interest rate (lagged by one year) proxies both financing costs and the economic conditions of a country. Inflation is also lagged by one year and proxies for the general financial stability of a country. Company taxes are taxes on income, profits, and capital gains in percent of revenue. Higher taxes potentially curb investments (Da Rin et al. 2006; Popov and Roosenboom 2013). As Zak and Knack (2001) argue that income equality fosters generalized trust within a society and potentially affects individualism, we further include the Gini coefficient which assumes a value of 0 for perfect income equality and 100 for perfect inequality. Tertiary education is the 
(a) Total sample

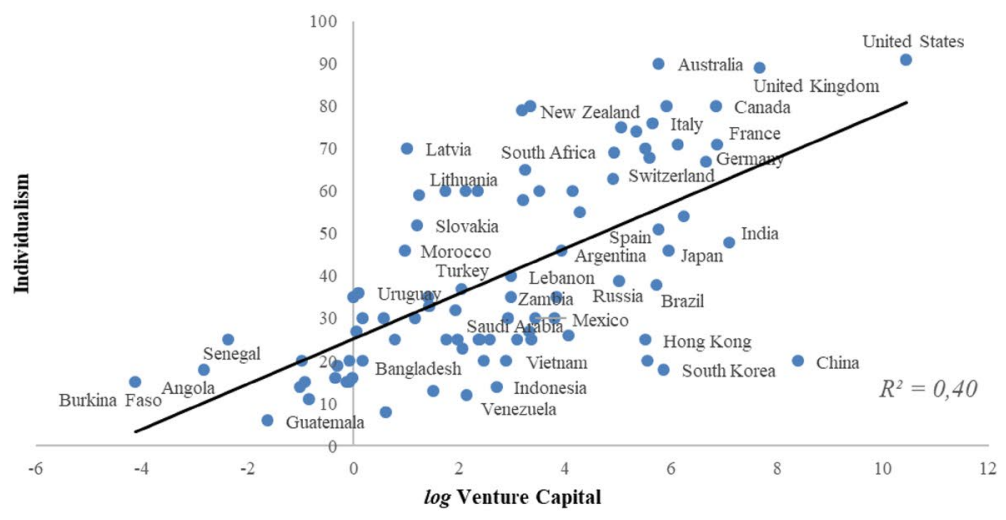

(b) High-income countries

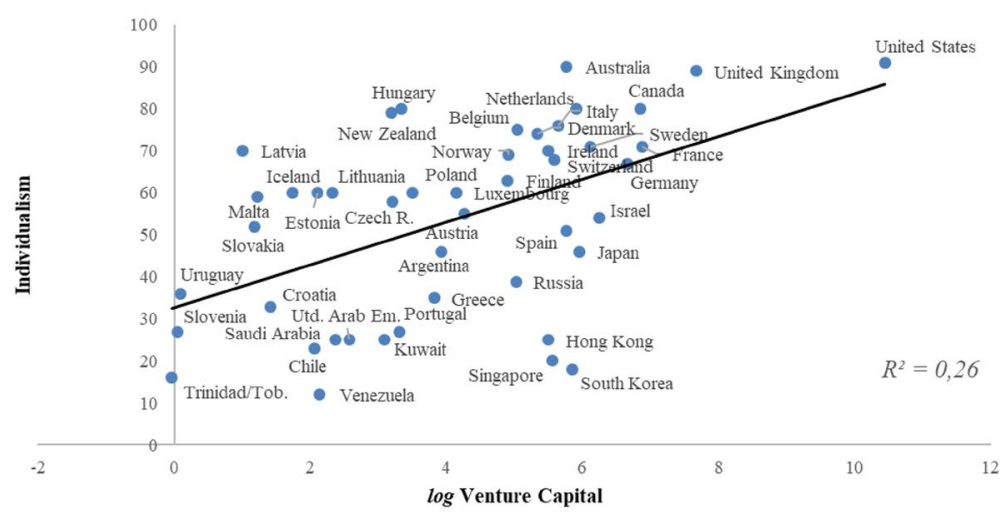

(c) Low-income countries

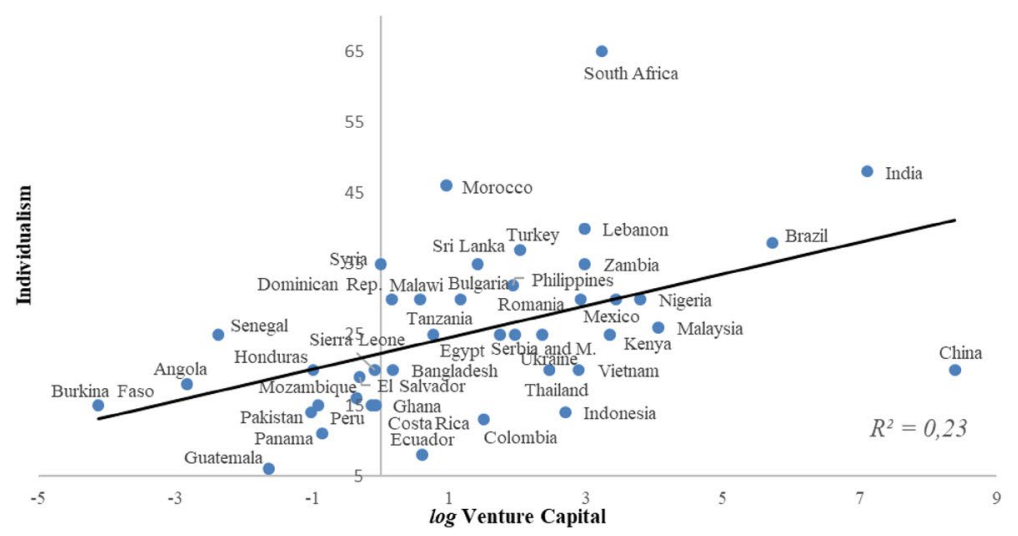

Fig. 3 Relation between individualism and venture-capital investments (log) 
fraction of labor force with tertiary education. Dearmon and Grier (2011) show that trust fosters education and education could thereby be interrelated with individualism. $R \& D$ expenditures is used as a proxy for the capacity of innovation of a country (Lerner and Tag 2013). Finally, life expectancy measures the number of years a newborn infant can expect to live. However, by adding these additional control variables, our sample is reduced to 924 country-year observations. ${ }^{8}$

In Table 6, column I, we first include economic factors, such as the unemployment rate, market capitalization to GDP or company taxes, which have been argued to affect venture-capital investments (see, e.g., Jeng and Wells 2000). In column II, we include variables that may capture the propensity to start an enterprise, such as tertiary education or R\&D expenditures. In column III both sets of variables are integrated. The empirical evidence shows that individualism does not lose its strongly significant and positive relationship with venture-capital investments.

\subsection{Language and Religion}

Groups that speak the same language or believe in the same religion often share the same values. Therefore, language and religion have been used as proxies for culture. As an example, Stulz and Williamson (2003) measure culture by language and religion when examining the effect of culture on investor rights. Several other authors use also a country's language and religion as a proxy for culture (see, e.g., Grinblatt and Keloharju 2001; Guiso et al. 2003, 2006). ${ }^{9}$ The advantage of this approach is that it allows researchers to aggregate countries along clearly defined dimensions (language and religion) (see Gupta et al. 2002; Ronen and Shenkar 1985; Schwartz 2014).

According to Hofstede (1980), language is the most important and recognizable element of culture. He argues that people speaking the same language within a specific territory share a common culture. Stulz and Williamson (2003) suggest that a common language facilitates the exchange of information. Similarly, Grinblatt and Keloharju (2001) track back the home bias to language. Finally, Kashima and Kashima (1998) find that languages in which pronouns are not dropped (e.g., English, French, and German) are more often spoken in countries with higher individualism than languages in which pronouns are dropped (Arabic, Spanish, Italian, and most Asian languages).

As language is an important expression of culture, we include six main languages in our analysis: Arabic, Chinese, English, French, German, and Spanish. Unfortunately, we are not able to include languages that are only spoken in one country (e.g., Swedish, Finnish, and Norwegian), because this variable would

\footnotetext{
${ }^{8}$ In cases in which control variables that are rather stable (e.g., life expectancy, tertiary education or company taxes) had missing values in single years, we replaced the missing values in order to save degrees of freedom by averages between two data points available or inserted available values before or after the missing values.

${ }^{9}$ A good survey on the effect of religion on economic development is provided by Aldashev and Platteau (2014).
} 
Table 6 Individualism, additional control variables and venture-capital investments

Log venture capital

(I) (II) (III)

\begin{tabular}{|c|c|c|c|}
\hline (Intercept) & $-10.75800 * * *(1.414)$ & $-10.69656^{* * *}(2.959)$ & $-8.39204 * * *(2.717)$ \\
\hline Individualism & $0.02573 * * *(0.007)$ & $0.03584 * * *(0.008)$ & $0.03468 * * *(0.008)$ \\
\hline GDP growth & $0.03972(0.025)$ & $0.02431(0.023)$ & $0.00124(0.027)$ \\
\hline Log GDP per capita & $-0.19447(0.166)$ & $-0.51764 *(0.311)$ & $-0.32486(0.234)$ \\
\hline Rule of law & $0.60865 * * *(0.199)$ & $0.34340(0.248)$ & $0.48118 * *(0.224)$ \\
\hline Exports & $-0.02809(0.019)$ & $0.00738(0.005)$ & $-0.03959 *(0.021)$ \\
\hline Population growth & $0.12257(0.096)$ & $0.05223(0.122)$ & $0.11554(0.133)$ \\
\hline Unemployment & $-0.02177(0.022)$ & & $-0.05152 * *(0.026)$ \\
\hline Market capitalization/GDP & $0.00111(0.002)$ & & $-0.00084(0.002)$ \\
\hline Foreign direct investments & $0.00651 *(0.004)$ & & $0.02994 * * *(0.011)$ \\
\hline Trade & $0.01874 *(0.010)$ & & $0.02376 * *(0.011)$ \\
\hline Real interest rate & $0.01118(0.008)$ & & $0.00642(0.010)$ \\
\hline Inflation & $0.00476 * *(0.002)$ & & $0.00398 * *(0.002)$ \\
\hline Company taxes & $-0.00078(0.009)$ & & $-0.00957(0.009)$ \\
\hline Gini coefficient & & $0.02774 *(0.016)$ & $0.02944 * *(0.014)$ \\
\hline Tertiary education & & $0.01661(0.012)$ & $0.01848 *(0.010)$ \\
\hline $\mathrm{R} \& \mathrm{D}$ expenditures & & $0.66885 * * *(0.178)$ & $0.61531 * * *(0.188)$ \\
\hline Life expectancy & & $0.03739(0.051)$ & $-0.02687(0.040)$ \\
\hline Log GDP & $1.12880 * * *(0.104)$ & $0.93079 * * *(0.094)$ & $1.02823 * * *(0.101)$ \\
\hline Years & Included & Included & Included \\
\hline Number of observations & 1265 & 968 & 924 \\
\hline $\mathrm{R}^{2}$ & 0.718 & 0.775 & 0.793 \\
\hline Adj. $R^{2}$ & 0.700 & 0.753 & 0.763 \\
\hline$F$-statistic & $104.7 * * *$ & $119.9 * * *$ & $103.1 * * *$ \\
\hline
\end{tabular}

The table presents regression coefficient estimates for individualism. The sample consists of 1496 country-year observations from 1998 to 2014. Cluster-robust standard errors are reported in parentheses. Significance at $1 \%, 5 \%$, and $10 \%$ levels is indicated by $* * *, * *$, and $*$, respectively

capture all other institutional factors of this specific country, i.e., it would act as a fixed effect for those countries.

Bjornskov (2007), Delhey and Newton (2005), and Knack and Keefer (1997) suggest that ethnic diversity within a country lowers trust and could therefore simultaneously affect individualism and curb venture-capital investments. It is possible that the cohabitation of people that speak different languages has a similar effect. Therefore, we include the variable linguistic index in the model, which measures fractionalization of languages within countries by using Herfindahl index from Alesina et al. (2003).

Table 7, columns I and II show that Chinese and French are positively related to venture-capital investments, whereas Arabic is negatively related to it. 
Table 7 Individualism, language, religion, and venture capital

\begin{tabular}{|c|c|c|c|c|}
\hline & \multicolumn{4}{|l|}{ Log venture capital } \\
\hline & (I) & (II) & (III) & (IV) \\
\hline (Intercept) & $\begin{array}{c}-7.43710^{* * * *} \\
\quad(0.889)\end{array}$ & $\begin{array}{l}-7.62491 * * * \\
\quad(1.042)\end{array}$ & $\begin{array}{l}-4.87365^{* * *} \\
\quad(1.214)\end{array}$ & $\begin{array}{l}-5.49119 * * * \\
(1.124)\end{array}$ \\
\hline Individualism & $\begin{array}{l}0.03015 * * * \\
(0.008)\end{array}$ & $\begin{array}{l}0.02961 * * * \\
(0.007)\end{array}$ & $\begin{array}{l}0.02531 * * * \\
(0.007)\end{array}$ & $0.02222 * * *(0.007)$ \\
\hline Arabic & $\begin{array}{l}-1.18816^{* * * *} \\
(0.341)\end{array}$ & $\begin{array}{l}-1.14841^{* * * *} \\
(0.338)\end{array}$ & & \\
\hline Chinese & $\begin{array}{c}2.91646 * * * \\
(0.483)\end{array}$ & $\begin{array}{c}2.97324 * * * \\
(0.530)\end{array}$ & & \\
\hline English & $0.43687(0.329)$ & $0.41467(0.338)$ & & \\
\hline French & $0.44153^{* *}(0.221)$ & $0.42266 *(0.233)$ & & \\
\hline German & $0.31601(0.315)$ & $0.29324(0.309)$ & & \\
\hline Spanish & $-0.26777(0.297)$ & $-0.23718(0.304)$ & & \\
\hline Linguistic index & & $0.20732(0.539)$ & & \\
\hline Buddhism & & & $\begin{array}{l}-1.75709 \text { *** } \\
(0.645)\end{array}$ & $\begin{array}{l}-1.88327 * * * \\
(0.573)\end{array}$ \\
\hline Catholicism & & & $\begin{array}{l}-1.74969 * * * \\
(0.626)\end{array}$ & $\begin{array}{l}-1.83681 * * * \\
(0.564)\end{array}$ \\
\hline Islam & & & $\begin{array}{l}-2.41389 * * * \\
(0.634)\end{array}$ & $\begin{array}{l}-2.44535^{* * * *} \\
(0.554)\end{array}$ \\
\hline $\begin{array}{l}\text { Orthodox Christi- } \\
\text { anity }\end{array}$ & & & $-1.32778 *(0.711)$ & $-1.42789 * *(0.665)$ \\
\hline Protestantism & & & $\begin{array}{c}-1.34466^{* * *} \\
(0.661)\end{array}$ & $\begin{array}{c}-1.67346^{* * * *} \\
(0.601)\end{array}$ \\
\hline Religious index & & & & $1.28718 * * *(0.414)$ \\
\hline Control variables & Included & Included & Included & Included \\
\hline Years & Included & Included & Included & Included \\
\hline $\begin{array}{l}\text { Number of obser- } \\
\text { vations }\end{array}$ & 1496 & 1496 & 1496 & 1496 \\
\hline $\mathrm{R}^{2}$ & 0.732 & 0.733 & 0.726 & 0.736 \\
\hline Adj. $\mathrm{R}^{2}$ & 0.717 & 0.718 & 0.712 & 0.721 \\
\hline$F$-statistic & $133.5 * * *$ & $129.9 * * *$ & $138.9 * * *$ & $141.1 * * *$ \\
\hline
\end{tabular}

The table presents regression coefficient estimates for individualism, religion, and language. The sample consists of 1496 country-year observations from 1998 to 2014. Cluster-robust standard errors are reported in parentheses. Significance at $1 \%, 5 \%$, and $10 \%$ levels is indicated by $* * *, * *$, and $*$, respectively

However, the inclusion of a country's language does not reduce the strong relation between individualism and venture capital.

Religion is another important expression of culture (Tarakeshwar et al. 2003). It influences norms, beliefs, and rules for behavioral relationships and creates identity. Several empirical studies document that religion influences economic performance (Glahe and Vorhies 1989; Noland 2005), the level of creditor rights (Stulz and Williamson 2003), the quality of government (La Porta et al. 1999), and corporate 
decisions (Hilary and Hui 2009). The values attributed to different religions have been argued to influence the society's perception of markets. According to Weber (1930), the Protestant work ethic has laid ground to capitalism and economic wealth. In fact, Hayward and Kemmelmeier (2011) find evidence that Protestant countries and Protestant people within countries have particularly pronounced pro-market attitudes. There is also strong empirical evidence that beliefs, values, and attitudes associated with religion, rather than religion itself, affect economic outcomes (see Arrunada 2010; Barro and McCleary 2003; Guiso et al. 2006; Hayward and Kemmelmeier 2011; La Porta et al. 1997). Protestants can also be seen as being more individualistic in their characteristics of pursuing economic success (Bjornskov 2007).

We include five major religions in our empirical analysis: Buddhism, Catholicism, Islam, Orthodox Christianity and Protestantism. According to several sources, Protestantism is expected to be positively related with venture-capital investments. Again, we do not include religions that are country-specific, such as Hinduism, because they would capture all other aspects of a given country. Similar to the use of a Linguistic index, we include the variable religious index that measures religious heterogeneity within a country (see Alesina et al. 2003).

Interestingly, the results in Table 7, columns III and IV indicate that all religions have a negative influence on venture-capital investments relative to the reference category 'other' which includes Daoism (in China), Hinduism, Judaism, Syncretism (in Zimbabwe), and local beliefs. Furthermore, the results also suggest that religious diversity is positively related to venture-capital investments, which, however, does not affect the positive relationship of individualism with venture capital.

\subsection{Formal Institutional Environment}

An efficient legal system that ensures abidance of contract provisions is vital for trade and economic development (see, e.g., Levine 2005). For example, in a wellfunctioning legal system, an entrepreneur who steals money will get prosecuted. In this respect, a functioning legal system will promote the transmission from ideas to products and services and, in consequence, lead to economic growth. Law (e.g., the protection of (intellectual) property rights) therefore is seen as a driver of innovation and growth; the lack of it may explain why some economies have failed to experience a positive development. Property rights increase financing available to firms and decrease their cost of capital (Hail and Leuz 2006; Rajan and Zingales 1998). Using a sample of 41 countries, Zak and Knack (2001) show that national growth rises with an increase in trust. One reason for this finding could be that countries with lower levels of trust create an unfavorable institutional environment for entrepreneurship and economic growth. For instance, Aghion et al. (2010) show that lowtrust countries are characterized by higher regulation. Several authors find evidence that individualism is positively related to investor protection (Han et al. 2010; Zhang et al. 2013), accountability, transparency (Griffin et al. 2014), and corporate governance (Haxhi and van Ees 2010). 
The theory of legal origins has been used to explain differences in economic systems and performance around the world. In a series of papers, La Porta et al. (1997, 1998, 2000, 2008) provide empirical evidence that French civil law offers lower investor protection in contrast to Common law which favors a more efficient allocation of capital and higher economic performance. The Legal Origins Hypothesis states that differences in legal rules and regulations can be attributed to the jurisdictions' legal origins (common-law countries are more focused on market-supporting regulations, such as investor protection, whereas civil-law countries rely on statecentered capitalistic policies) and that these differences have an effect on economic outcomes. It is important to note, however, that also the level of investor protection might be a consequence of a country's culture or level of individualism (see, e.g., Roe 2003).

In addition to the variable rule of law of our baseline model, we also include in our regressions the dummy variables Common law, French civil law, German civil law, Nordic civil law, and Socialistic law (mixed law serves as reference variable). We obtain information on the origin of the legal system from Djankov et al. (2007) and NYU's GlobaLex.

To account for the positive relationship between formal institutions and venturecapital investments documented in Li and Zahra (2012), we include in the regressions the overall score of worldwide governance indicator (World Bank), ${ }^{10}$ strength of legal rights index (World Bank; $0=$ weak to $10=$ strong), economic freedom overall score (Heritage Foundation), and corruption perceptions index (Transparency International). For all indicators, a higher number stands for a better score.

Table 8 shows the regression results controlling for the possible effect of formal institutions. All indices measuring the quality of formal institutions except for Economic freedom overall score are positively and significantly related to venture-capital investments. In column I Nordic civil law has a positive and significant coefficient. However, once the other formal institution variables are included (column IV), the significance of Nordic civil law vanishes.

\subsection{Cultural Dimensions}

Beside the dichotomy individualism-collectivism, Hofstede (1980) mentions power distance, uncertainty avoidance, and masculinity-femininity as other important cultural dimensions. Licht et al. (2005) show that power distance (i.e., greater tolerance for hierarchy) is negatively related to investor protection, which may restrain people to invest. Gupta et al. (2004) argue that higher power distance is detrimental to entrepreneurship. Shane $(1992,1993)$ suggests that higher power distance is negatively related to innovation. Finally, also negotiations have been argued to suffer in case of higher power distance (Chan and Cheung 2016). In countries with a high level of uncertainty avoidance, people may worry more about the unknown future.

\footnotetext{
${ }^{10}$ WGI is the equally weighted average of all six governance dimensions: The index consists of voice and accountability, political stability and absence of violence/terrorism, government effectiveness, regulatory quality, rule of law, and control of corruption.
} 


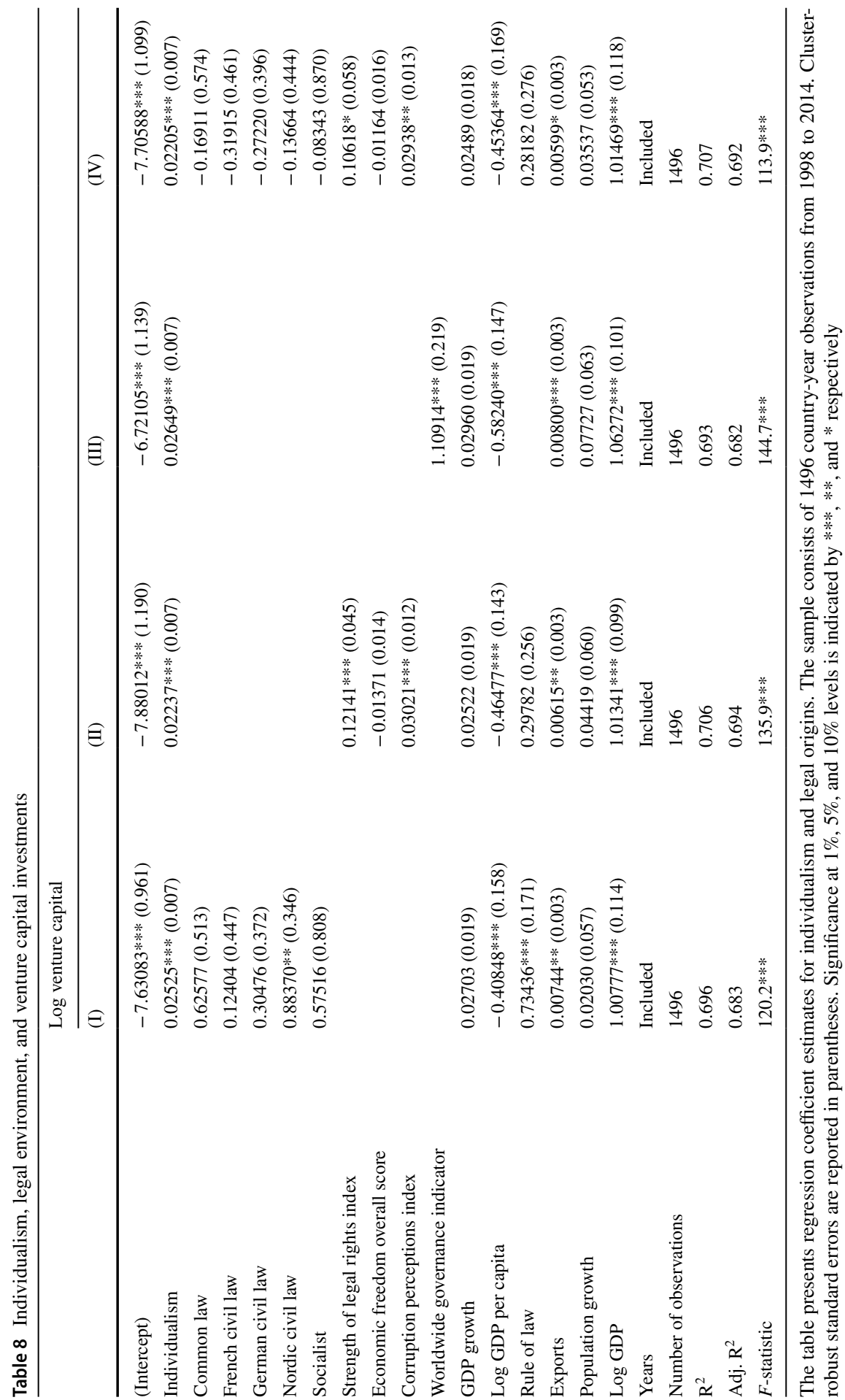


Table 9 Cultural dimensions, trust, and venture-capital investments

\begin{tabular}{|c|c|c|c|}
\hline & \multicolumn{3}{|l|}{ Log venture capital } \\
\hline & (I) & (II) & (III) \\
\hline (Intercept) & $-5.98180 * * *(1.136)$ & $-7.54792 * * *(1.343)$ & $-7.89877 * * *(1.140)$ \\
\hline Individualism & $0.01908 * * *(0.007)$ & $0.01992 * * *(0.007)$ & $0.02624 * * *(0.007)$ \\
\hline Power distance & $-0.01102(0.010)$ & $0.00091(0.009)$ & \\
\hline Uncertainty avoidance & $-0.01676 * * *(0.006)$ & $-0.02034 * * *(0.006)$ & \\
\hline Masculinity & $-0.00666(0.004)$ & $-0.00948 * *(0.005)$ & \\
\hline Long-term orientation & & $0.01055 *(0.006)$ & \\
\hline Indulgence & & $0.00620(0.005)$ & \\
\hline Trust & & & $0.00745(0.005)$ \\
\hline GDP growth & $0.01569(0.016)$ & $0.01653(0.017)$ & $0.03290 *(0.019)$ \\
\hline Log GDP per capita & $-0.29877 * *(0.118)$ & $-0.28464 *(0.160)$ & $-0.44181 * * *(0.146)$ \\
\hline Rule of law & $0.54225 * * *(0.183)$ & $0.65642 * * *(0.179)$ & $0.76272 * * *(0.180)$ \\
\hline Exports & $0.00569 * *(0.003)$ & $0.00370(0.003)$ & $0.00851 * * *(0.003)$ \\
\hline Population growth & $0.01626(0.057)$ & $-0.04399(0.101)$ & $0.10302(0.093)$ \\
\hline Log GDP & $1.03806^{* * *}(0.096)$ & $1.05668 * * *(0.097)$ & $1.03192 * * *(0.083)$ \\
\hline Years & Included & Included & Included \\
\hline Number of observations & 1496 & 1258 & 1411 \\
\hline $\mathrm{R}^{2}$ & 0.709 & 0.735 & 0.703 \\
\hline Adj. $\mathrm{R}^{2}$ & 0.696 & 0.718 & 0.691 \\
\hline$F$-statistic & $137.4 * * *$ & $121.8 * * *$ & $137.0 * * *$ \\
\hline
\end{tabular}

The table presents regression coefficient estimates for cultural dimensions. The sample consists of 1496 country-year observations from 1998 to 2014. Cluster-robust standard errors are reported in parentheses. Significance at $1 \%, 5 \%$, and $10 \%$ levels is indicated by $* * *, * *$, and $*$, respectively

A culture of uncertainty avoidance has been argued to be an obstacle to venturecapital investments (Hofstede 1980) and has been associated with Continental European countries rather than Anglo-Saxon countries. Shane $(1993,1995)$ finds a negative relationship between uncertainty avoidance and innovation or entrepreneurship. Research also suggests that higher uncertainty avoidance scores relate to higher risk-aversion (Beugelsdijk and Frijns 2010; Chui and Kwok 2008; Frijns et al. 2013; Kwok and Tadesse 2006; Rieger et al. 2015). Finally, masculinity describes a society's preferences for achievement and material rewards for success.

We include power distance, uncertainty avoidance, masculinity as well as the newer dimensions of culture by Hofstede (long-term orientation and indulgence, see HHM 2010) into our model. The results in Table 9 indicate that uncertainty avoidance and masculinity are negatively related to venture capital, while long-term orientation is positively related to it. Furthermore, and surprisingly, the additional 
variable trust ${ }^{11}$ is not linked to venture capital. Importantly, in all these models, individualism remains strongly and significantly related to venture-capital investments.

\subsection{Geographic Conditions}

Research also suggests that the geographical location of a country and health conditions within countries affect economic outcomes, such as economic growth (see, e.g., Acemoglu et al. 2001; Gorodnichenko and Roland 2017; Sachs and Malaney 2002). Therefore, we include internal distance of country, landlocked, and latitude from GeoDist Database by CEPII, and malaria infections from Geography Datasets by Gallup et al. (1999). Our results suggest, however, that geography plays a minor role in explaining differences in venture-capital investments across countries (results not reported).

\subsection{Moderating and Mediating Effects}

Based on the insights from new institutional theory (North 1990, 1994; Scott 1995; Williamson 2000) that formal and informal institutions affect economic outcomes in both a direct and indirect way, in this section we aim at shedding light on the nature of the previously established relationship between individualism and venture-capital investments. In particular, we investigate whether the influence of individualism on venture capital is moderated and/or mediated by formal and informal institutions as suggested by institutional theorists.

With respect to possible moderating effects of this relationship, we consider variables related to economic conditions as well as countries' formal and informal institutions and interact them with individualism. In Table 10, we report the results for selected variables that, based on the theoretical considerations presented in Sect. 2.3, we deem as particularly plausible moderators of the effect of individualism on venture-capital investments because they are related to entrepreneurial attitudes (uncertainty avoidance), the quality of formal institutions (rule of law), generalized trust (trust), and economic conditions (GDP per capita). Specifically, we create dummy variables that take the value of 1 if the values of the related continuous variables are either in the highest or in the lowest quartile, respectively. In all models, individualism has a positive and significant effect on venture capital. Furthermore, in Table 10, Regression I, the interaction of GDP per capita high with individualism is positive and significant, which indicates that the influence of individualism on venture-capital investments always exists but that it is particularly strong in more-developed countries with higher GDP per capita. Interestingly, no moderating effect could be found in the data with respect to entrepreneurial attitudes, formal institutions, and generalized trust. Additionally, we have tested in the same fashion (not reported)

\footnotetext{
11 The variable Trust is obtained from World Value Survey and measures generalized trust by asking people the following question: "Generally speaking, would you say that most people can be trusted, or that you can't be too careful in dealing with people?".
} 


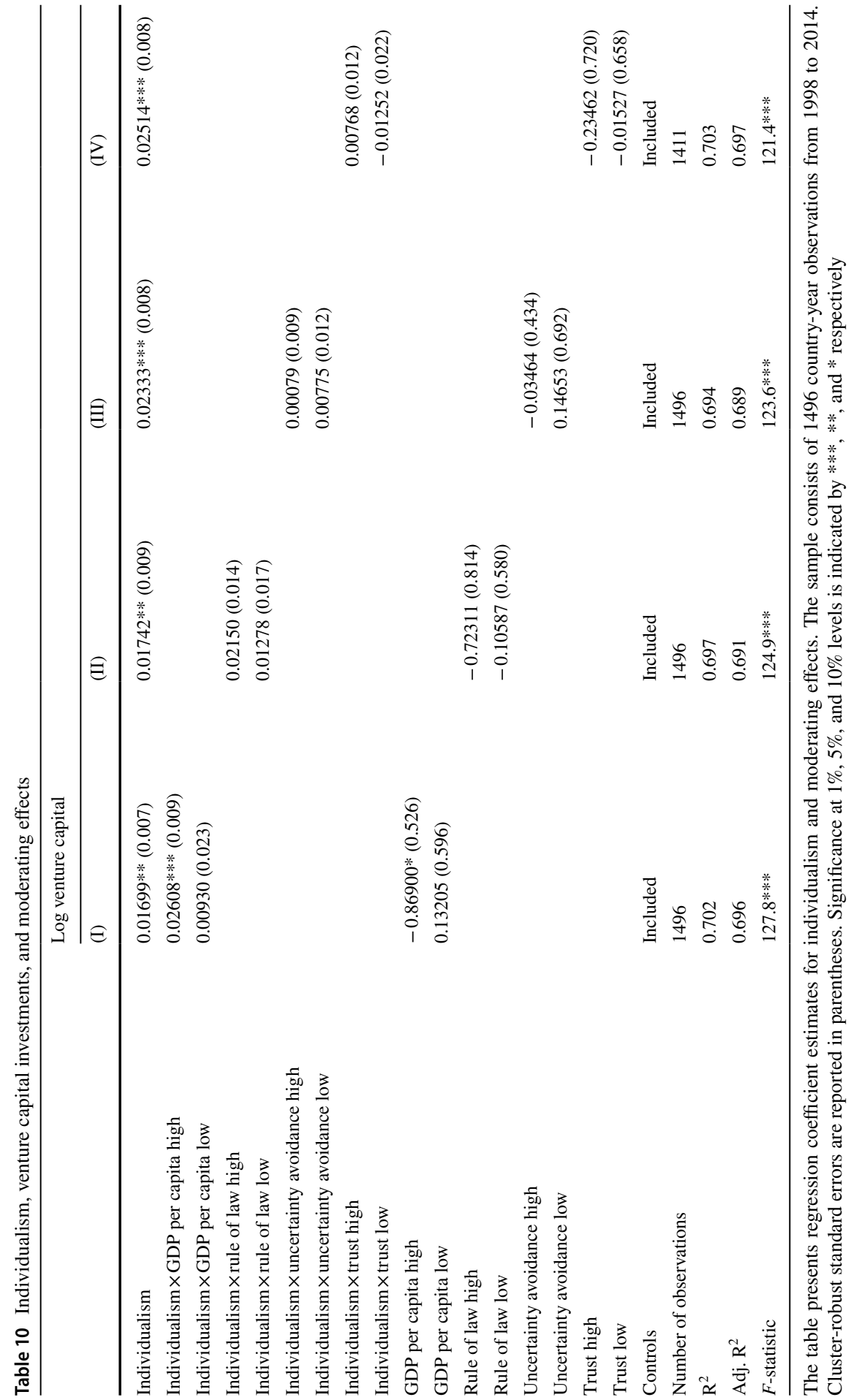


(a) GDP per capita

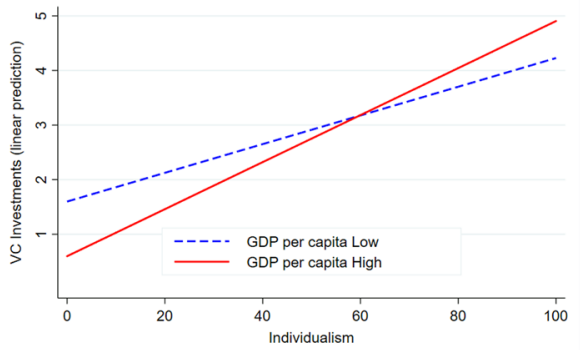

(c) Uncertainty avoidance

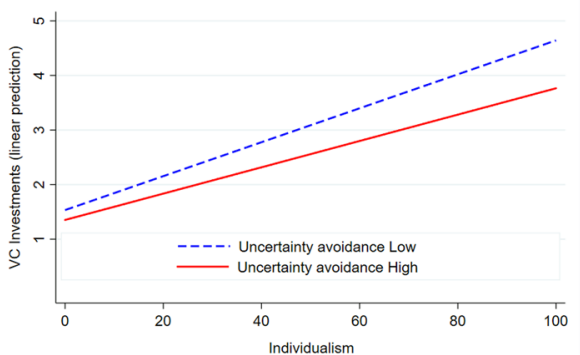

(b) Rule of law

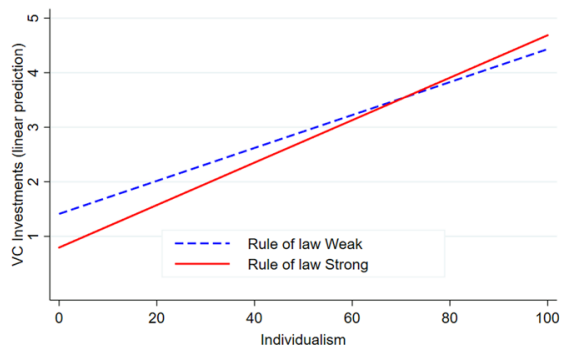

(d) Trust

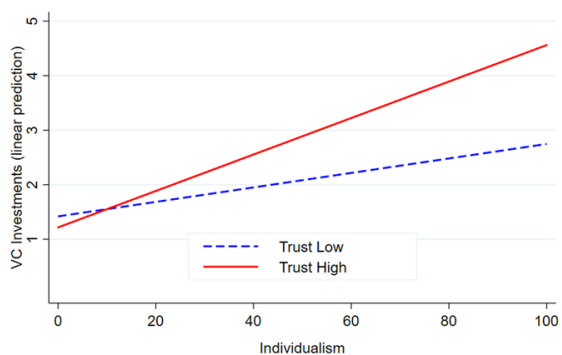

Fig. 4 Interaction-effect graphs for the moderating variables a GDP per capita, b rule of law, $\mathbf{c}$ uncertainty avoidance, and $\mathbf{d}$ trust

moderating effects related to religion (Buddhism, Catholicism, Orthodox, Protestant, and other) and Hofstede's other cultural variables (masculinity, power distance, long-term orientation, and indulgence). In all regressions, individualism remained positive and significant. Further, only in the case of long-term orientation, the interaction term with individualism was negative and significant (t-value -2.05), which may indicate that individualism and long-term orientation are partial substitutes in promoting venture-capital investments. No other moderating effect was detected.

In Fig. 4, we provide interaction-effect graphs for the moderating effects of the variables (a) GDP per capita, (b) rule of law, (c) uncertainty avoidance, and (d) trust by showing the relation between individualism and the marginal linear predictions of venture-capital investments for high and low values of the corresponding moderating variable. Remarkably, the slopes are positive in all graphs, which indicates a consistent and positive cross-country relation between individualism and venturecapital investments. Further, countries with higher GDP per capita, stronger rule of law, lower uncertainty avoidance, and higher trust display a more pronounced relationship between individualism and venture-capital investments. However, only in the case of high-income countries (panel (a)), this difference is statistically significant (as previously shown in Table 10).

To test for the presence of mediating effects, we follow Baron and Kenny's (1986) established three-step procedure. First, we estimate the influence of individualism on the mediating variable (by including controls). Second, we regress venture-capital investments on individualism (with controls but without the mediating variable). 
Third, we estimate a model to explain venture-capital investments that includes both individualism and the mediating variable. To exert a mediating effect, a variable should (1) be significantly related to individualism in the first-step regression, (2) affect venture-capital investments in the third-step regression, and (3) lead to a significant reduction of the coefficient of individualism when moving from the secondstep regression to the third-step regression (we follow Hicks and Tingley (2012) and measure the indirect effect by means of bootstrapping).

Based on the theory presented in Sect. 2.3, entrepreneurial attitudes (uncertainty avoidance), the quality of formal institutions (rule of law), generalized trust (trust), and economic conditions (GDP per capita) are likely to mediate the effect of individualism on venture-capital investments. As shown in Table 11, out of the four main variables, uncertainty avoidance and rule of law are actually found to partially mediate the effect of individualism on venture-capital investments. Their mediation is, however, not complete because the coefficient of individualism on venture-capital investments decreases from the second-step to the third-step regression but it remains positive and significant also when including any of these mediators in the third-step regression. In particular, the indirect effects of individualism on venturecapital investments mediated by uncertainty avoidance and rule of law amount to $27.08 \%$ and $35.94 \%$ of the total effect (i.e., direct plus indirect effect), respectively (results unreported). On the contrary, GDP per capita and trust cannot be mediators because they are both unrelated to individualism (see Table 11, first equation).

\subsection{Addressing Endogeneity with an Instrumental-Variable Approach: Polity Score}

Endogeneity caused by omitted variables and simultaneity may flaw our empirical analysis. We therefore tackled the omitted-variable bias by including numerous control variables. Simultaneity may not present a significant issue in our analysis because culture and the prevailing system of beliefs, values, and norms that affect individualism are deeply rooted within a society and evolve only very slowly (Hofstede 1980). In this respect, Licht (2001) defines culture as the 'mother of all path dependencies'. However, in order to exclude the potential issues of endogeneity, we employ an instrumental-variable approach.

In particular, we use the Revised Combined Polity Score (polity score) from the Polity IV Project 'Political Regime Characteristics and Transitions, 1800-2014' as an instrument for individualism. ${ }^{12}$ The score ranks political systems on a scale from -10 (strongly autocratic) to +10 (strongly democratic) by subtracting the score of 'Institutionalized autocracy' from 'Institutionalized democracy'. We use the average of this score from 1816 (just after Congress of Vienna) to 1913 (just before World War I). ${ }^{13}$ For example, during this period Thailand obtained a value of -10 (strongly autocratic) while Switzerland received a value of +10 (strongly

\footnotetext{
12 http://www.systemicpeace.org/inscr/p4v2014.xls.

13 For countries that did not exist in 1816, we compute the polity score average from the foundation year to 1912. For example, in the case of Italy 1861-1913.
} 


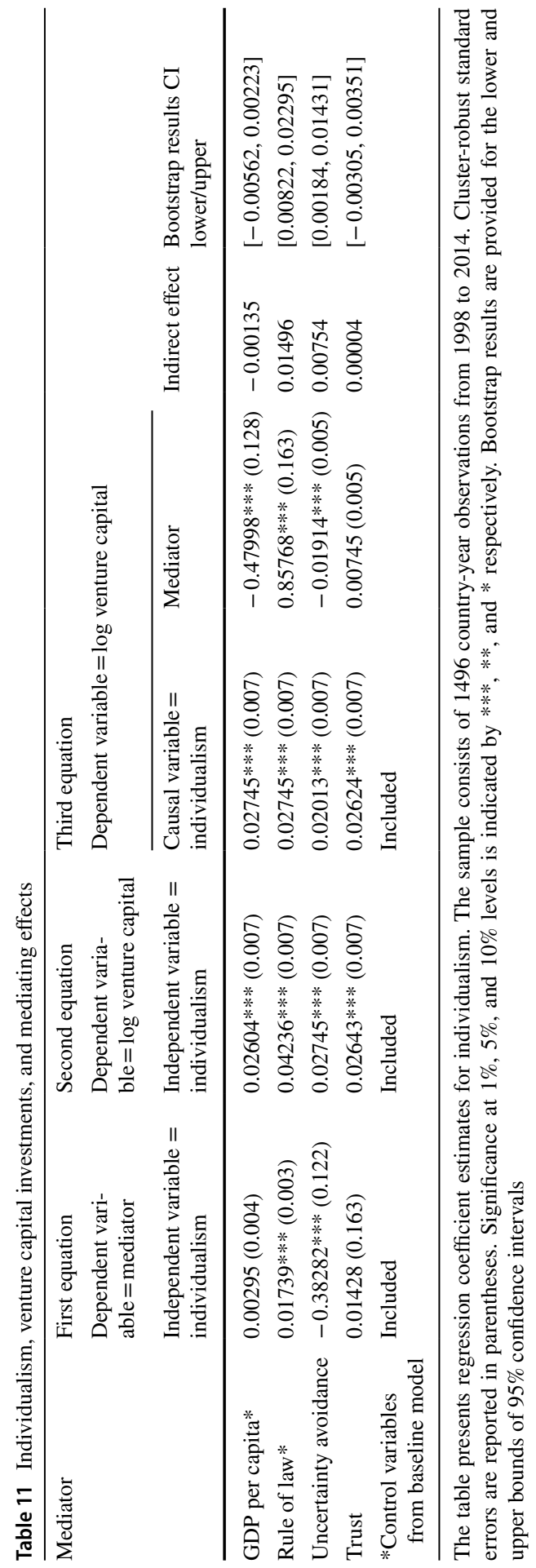


Table 12 Instrumental variable approach: Polity score

\begin{tabular}{llll}
\hline & First stage & Reduced-form & Second stage \\
\hline & Individualism & Log venture capital & Log venture capital \\
(Intercept) & $-33.56959(34.570)$ & $-5.05627 *(2.290)$ & $-8.02994 * *(1.084)$ \\
Individualism & & & $0.06314^{* * *}(0.014)$ \\
Polity score & $0.92692^{* *}(0.453)$ & $0.05431(0.038)$ & \\
GDP growth & $-0.63791^{* *}(0.316)$ & $0.03227^{* * *}(0.010)$ & $0.07655^{* * *}(0.021)$ \\
Log GDP per capita & $3.64810(4.519)$ & $-0.85684^{* * *}(0.323)$ & $-0.54561 * * *(0.139)$ \\
Rule of law & $9.34809^{* *}(4.354)$ & $1.20739^{* * *}(0.305)$ & $0.19600(0.197)$ \\
Exports & $0.06923(0.089)$ & $0.01221^{* *}(0.005)$ & $0.00801 * * *(0.003)$ \\
Population growth & $-3.35639(2.147)$ & $0.02828(0.105)$ & $-0.03377(0.074)$ \\
Log GDP & $3.85676^{* *}(1.504)$ & $1.23560^{* * *}(0.138)$ & $1.04341^{* * *}(0.066)$ \\
Years & Included & Included & Included \\
Number of observations & 782 & 901 & 782 \\
$\mathrm{R}^{2}$ & 0.677 & 0.747 & 0.725 \\
Adj. R & 0.656 & 0.728 & 0.703 \\
$F$-statistic & $68.9 * * *$ & $112.8 * * *$ & $83.9 * * *$ \\
\hline
\end{tabular}

The table presents regression coefficient estimates for individualism. The sample consists of 782 country-year observations from 1998 to 2014. Standard errors are reported in parentheses. Significance at $1 \%$, $5 \%$, and $10 \%$ levels is indicated by $* * *, * *$, and $*$, respectively

democratic). The Congress of Vienna has set many long-lasting territorial borders and has stabilized Europe for almost 100 years until World War I, despite the revolutions of the mid-nineteenth-century. Considering earlier historical eras appears inappropriate because, from a historical perspective, the modern concept of individualism has become important for the first time in history during the Renaissance (fourteenth to seventeenth century) (Burckhardt 1867). It is reasonable that the political settings in the period from 1816 to 1913 have influenced peoples' attitudes toward individual freedom, personal responsibility, reward attitude, and self-orientation-traits which are all associated with individualism. As some countries did not exist at the time (e.g., Croatia or Ukraine) or were not covered by polity score, the choice of this instrument reduces the sample to 782 country-year observations.

First-stage regressions in Table 12 show that polity score is relevant as it is positively and significantly related to individualism. The $F$ test of 23.6 exceeding the rule of thumb threshold of 10 shows that the instrument is relevant (see Staiger et al. 1997). As we have only one instrument for our endogenous variable and the model is therefore exactly identified, we cannot test the exogeneity of the instrument. However, reduced-form regressions indicate that our instrument is not directly related to venture-capital investments (the same is true if individualism is also included in the regression). We are therefore confident that our instrument is valid. Importantly, no direct impact of the political system 200 years ago can be expected on today's venture-capital investments, which offers a strong argument for the exogeneity of the instrument (see, e.g., Wooldridge 2010). The results of the two-stage-least square 
regression indicate that individualism is still positively related to venture-capital investments.

\subsection{Robustness Checks}

We round off the analysis by performing a battery of robustness checks. First, in Table 13 we re-run the baseline models by using different specifications of venture-capital investments: venture capital/GDP, number of transactions/population, and seed. Seed is the volume of seed capital, i.e., the first stage of venture capital invested in start-ups.

With all three dependent variables (Table 13, columns I-III), the relationship between individualism and venture capital remains positive and significant. Also, when running Logit (column IV), Tobit (column V), and Random effects models (column VI), the results are qualitatively equivalent.

Higher venture-capital investments may also depend on the existence of specific providers of risk capital within a country, namely individuals and governments. As Brander et al. (2015) show, venture capital sponsored by governments increases total venture-capital investments within a country. Our results show that also the existence of such particular groups of investors does not affect the relationship between individualism and venture-capital investments (results not reported). Additionally, we use supply rather than demand of venture capital as our dependent variable. However, also in this case the results do not change.

We also run regressions on a variety of subsamples to check whether the findings are driven by specific countries. As shown in Table 14 (and depicted in Fig. 3b, c), individualism remains positively and significantly related to venture-capital investments across different sets of income groups even when excluding large countries, such as the United States and China that account for $67.3 \%$ and $8.6 \%$ of total venture-capital volume in the sample, respectively. Finally, individualism remains strongly related to venture-capital investments during the two periods of financial crises, 2000-2003 and 2007-2009 (results not reported).

\section{Conclusion}

Venture capital is essential for economic growth and prosperity. Nevertheless, the high growth perspectives of start-ups and the potential returns that go along with them are associated with substantial risk on the side of entrepreneurs and investors. Due to its high risk, venture capital has been argued to be undersupplied in countries characterized by specific cultural elements. Individualism, which is intrinsically related with values of individual freedom, personal responsibility, and reward, is a driving factor of entrepreneurial spirit and, thus, venture-capital investments. By accounting for economic conditions, (formal) institutional factors, and other cultural aspects, our results show that individualism increases venture-capital investments, even after controlling for endogeneity. This result remains robust in a variety of settings. The effect of individualism on venture-capital investments is found to 


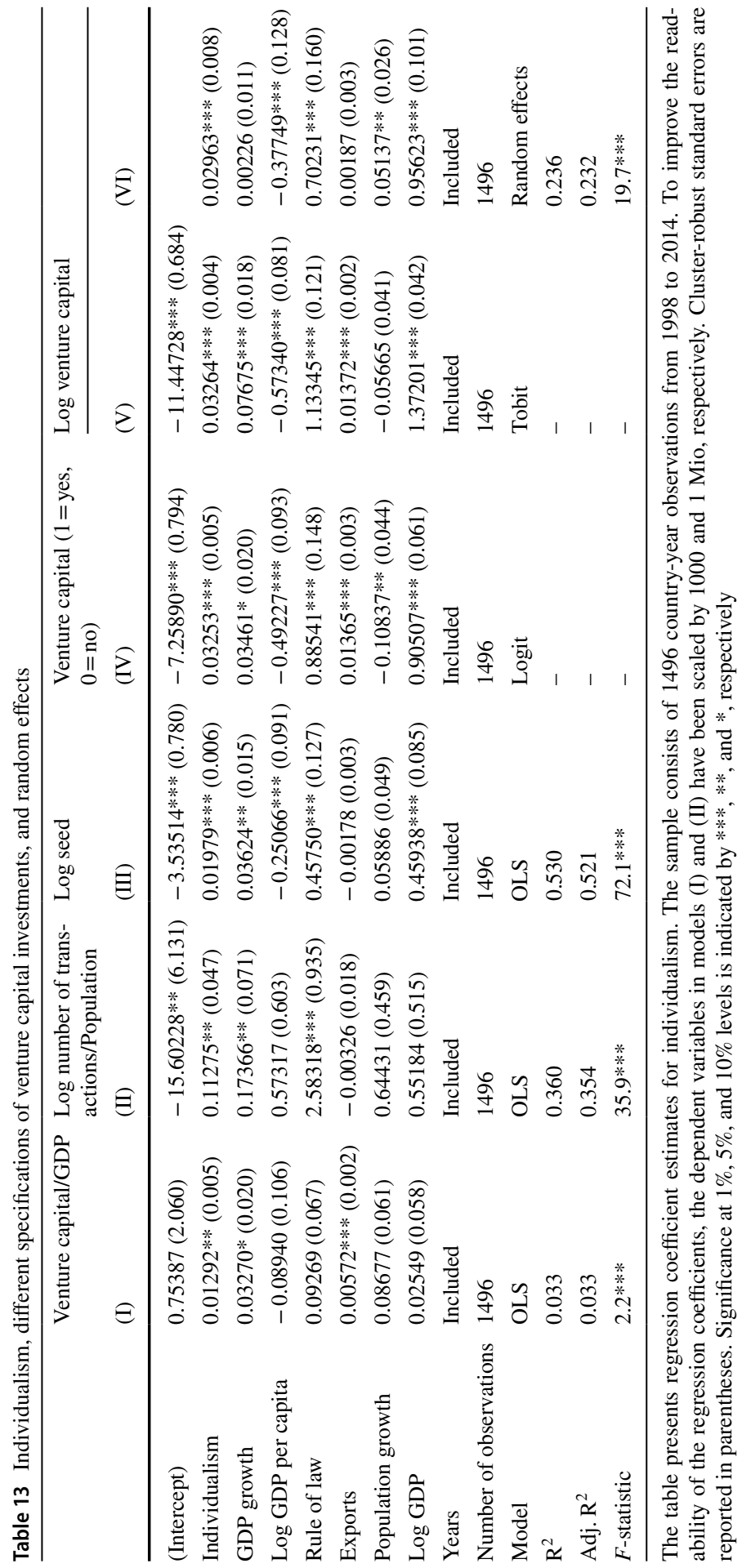




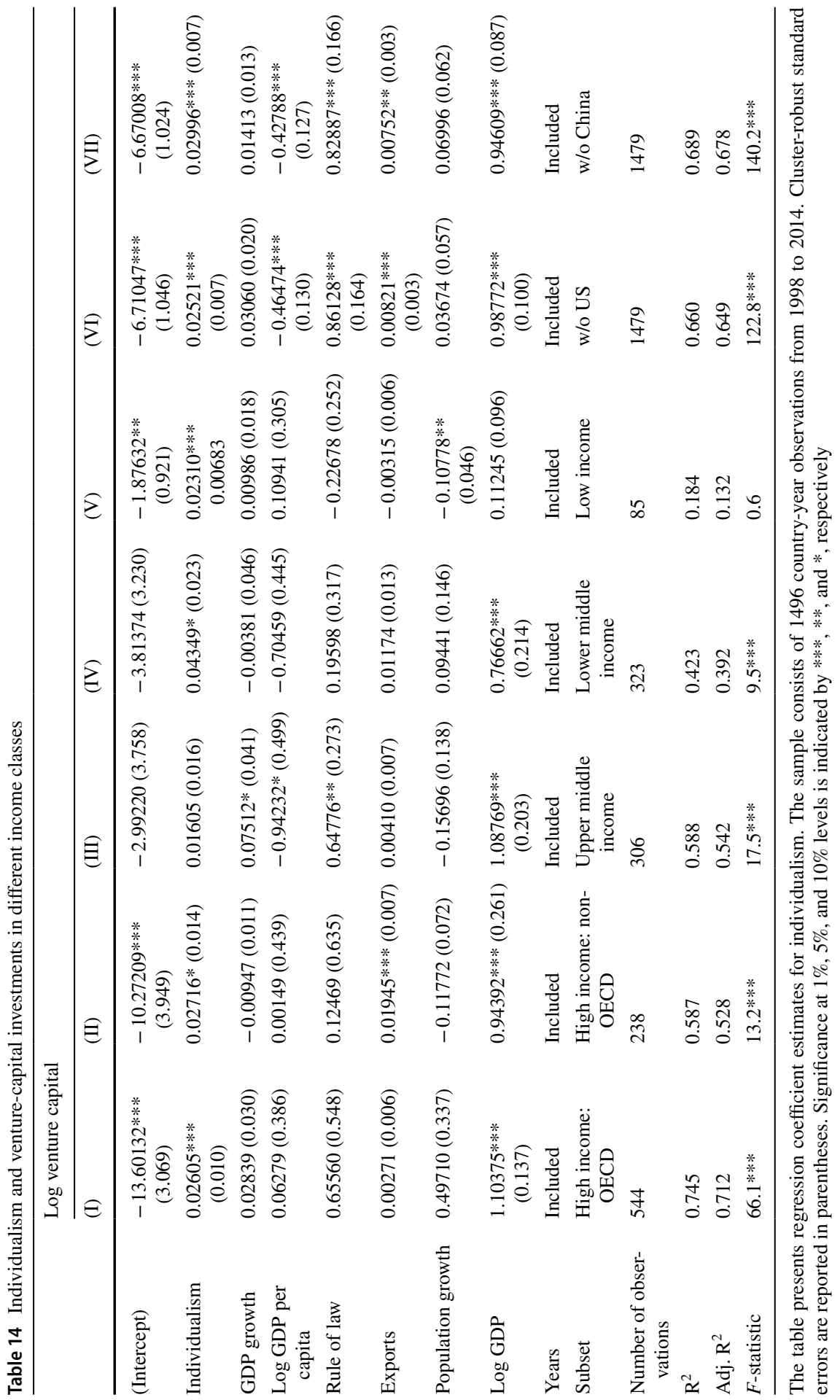


be partially mediated by the quality of formal institutions (rule of law) and entrepreneurial attitudes (uncertainty avoidance), and moderated by economic conditions (GDP per capita).

Governmental market interventions are usually justified by market failures, e.g., the presence of asymmetrically distributed information, negative externalities, monopolies, and public goods (positive externalities). Even though it is difficult to identify market failures, venture capital is potentially affected by strong information asymmetries and positive externalities similar to those that affect the provision of public goods. Measures directed towards improving the supply of venture capital have most often aimed at strengthening the (formal) institutional environment. However, governments that attempt to promote venture-capital investments should be aware that not all recipes that work in one country are applicable to others. As shown in this study, this may be due to fundamental cultural differences across countries. In countries with low levels of individualism, politics could rather make campaigns to inform about the (social) benefits of entrepreneurship. Further, venture capitalists involved in cross-border investments should consider cultural differences across countries in order to exploit the opportunities of new international markets.

Along with these novel findings, our study has some limitations. First of all, individualism may not be the best proxy of entrepreneurial spirit. For example, it has been suggested that individualism may lead to overconfidence (Chen et al. 2015; Van Den Steen 2004). Hence, overconfidence-rather than individualism-may result in higher venture-capital investments. Furthermore, corporate venture capital, corporate entrepreneurship, and corporate innovation may be underestimated in our data. In collectivistic countries, such as Japan, entrepreneurship may also occur in existing corporations and may be driven by the existence of high levels of loyalty within Japanese corporations (similar to families). Additionally, there are countries, such as Belgium, Canada, Finland, Sweden, and Switzerland, in which different "cultures" cohabit. In our study, however, also due to the lack of regional data on individualism and control variables, we rely on within-country averages of individualism and perform a cross-country study. We rely on data of Thomson ONE Banker which registers venture-capital transactions from various sources. Nevertheless, in some countries, start-up financing may be provided from sources for which information is not disclosed, e.g., for reasons of confidentiality. Such venture-capital investments will also not appear in Thomson ONE Banker's database. As this selective reporting could be more pronounced in collectivist countries, we cannot exclude biased results. Additionally, data does not include venture debt or mezzanine finance to start-ups, which may underestimate the magnitude of venture-capital investments in countries with more developed debt markets. Finally, some controls that stem from the World Bank database are often not available for countries in emerging markets, which complicates the task of evaluating the effect of individualism on venture-capital investments around the world.

Acknowledgements We would like to thank participants at the 5th International Research Meeting in Business and Management, the 14th EBES Conference, the 2015 World Conference on Business and Management, the 2016 World Finance Conference (discussant Georgios Panos), Maastricht University, the 2016 World Finance Banking Symposium (discussant Jeremy Goh), the 2nd World Congress of 
Comparative Economics, and the 2017 EFMA annual meeting (discussant Anita Quas) for their helpful comments on this and earlier drafts.

Open Access This article is distributed under the terms of the Creative Commons Attribution 4.0 International License (http://creativecommons.org/licenses/by/4.0/), which permits unrestricted use, distribution, and reproduction in any medium, provided you give appropriate credit to the original author(s) and the source, provide a link to the Creative Commons license, and indicate if changes were made.

\section{References}

Acemoglu, D., Johnson, S., \& Robinson, J. A. (2001). The colonial origins of comparative development: An empirical investigation. American Economic Review, 91(5), 1369-1401.

Aggarwal, R., \& Goodell, J. W. (2010). Financial markets versus institutions in European countries: Influence of culture and other national characteristics. International Business Review, 19(5), 502-520.

Aggarwal, R., \& Goodell, J. W. (2013). Political-economy of pension plans: Impact of institutions, gender, and culture. Journal of Banking and Finance, 37(6), 1860-1879.

Aghion, P., Algan, Y., Cahuc, P., \& Shleifer, A. (2010). Regulation and distrust. The Quarterly Journal of Economics, 125(3), 1015-1049.

Ahern, K. R., Daminelli, D., \& Fracassi, C. (2015). Lost in translation? The effect of cultural values on mergers around the world. Journal of Financial Economics, 117(1), 165-189.

Aldashev, G., \& Platteau, J. P. (2014). Religion, culture and development. In V. Ginsburgh, \& D. Throsby (Eds.), Handbook of the economics of art and culture (Vol. 2) (pp. 587-631). Amsterdam: Elsevier and North-Holland.

Alesina, A., Devleeschauwer, A., Easterly, W., Kurlat, S., \& Wacziarg, R. (2003). Fractionalization. Journal of Economic Growth, 8(2), 155-194.

Algan, Y., \& Cahuc, P. (2010). Inherited trust and growth. American Economic Review, 100(5), 2060-2092.

Allik, J., \& Realo, A. (2004). Individualism-collectivism and social capital. Journal of Cross-Cultural Psychology, 35(1), 29-49.

Amit, R., Brander, J., \& Zott, C. (1998). Why do venture capital firms exist? Theory and Canadian evidence. Journal of Business Venturing, 13(6), 441-466.

Ang, J. B. (2015). Agricultural legacy, individualistic culture, and technology adoption. EGC Report No. 2015/06.

Ang, J. S., Cheng, Y., \& Wu, C. (2015). Trust, investment, and business contracting. Journal of Financial and Quantitative Analysis, 50(3), 569-595.

Anokhin, S., \& Schulze, W. S. (2009). Entrepreneurship, innovation, and corruption. Journal of Business Venturing, 24(5), 465-476.

Armour, J., \& Cumming, D. (2006). The legislative road to Silicon Valley. Oxford Economic Papers-New Series, 58(4), 596-635.

Arrunada, B. (2010). Protestants and Catholics: Similar work ethic, different social ethic. The Economic Journal, 120(547), 890-918.

Banfield, E. C. (1958). The moral basis of a backward society. New York: The Free Press.

Barro, R. J., \& McCleary, R. M. (2003). Religion and economic growth across countries. American Sociological Review, 68(5), 760-781.

Baron, R. M., \& Kenny, D. A. (1986). The moderator-mediator variable distinction in social psychological research: Conceptual, strategic and statistical considerations. Journal of Personality and Social Psychology, 51(6),1173-1182.

Beck, T., Demirgüç-Kunt, A., \& Levine, R. (2003). Law, endowments, and finance. Journal of Financial Economics, 70(2), 137-181.

Beugelsdijk, S., \& Frijns, B. (2010). A cultural explanation of the foreign bias in international asset allocation. Journal of Banking and Finance, 34(9), 2121-2131.

Beugelsdijk, S., Kostova, T., \& Roth, K. (2017). An overview of Hofstede-inspired country-level culture research in international business since 2006. Journal of International Business Studies, 48(1), $30-47$. 
Bjornskov, C. (2007). Determinants of generalized trust: A cross-country comparison. Public Choice, $130(1-2), 1-21$.

Black, B. S., \& Gilson, R. J. (1998). Venture capital and the structure of capital markets: Banks versus stock markets. Journal of Financial Economics, 47(3), 243-277.

Bohnet, I., \& Zeckhauser, R. (2004). Trust, risk and betrayal. Journal of Economic Behavior and Organization, 55(4), 467-484.

Bottazzi, L., Da Rin, M., \& Hellmann, T. (2016). The importance of trust for investment: Evidence from venture capital. Review of Financial Studies, 29(9), 2283-2318.

Brander, J. A., Du, Q., \& Hellmann, T. (2015). The effects of government-sponsored venture capital: International evidence. Review of Finance, 19(2), 571-618.

Bruton, G. D., Fried, V. H., \& Manigart, S. (2005). Institutional influences on the worldwide expansion of venture capital. Entrepreneurship Theory and Practice, 29(6), 737-760.

Burckhardt, J. (1867). Die Kultur der Renaissance in Italien.

Chan, A. W., \& Cheung, H. Y. (2016). Extraversion, individualism and M\&A activities. International Business Review, 25(1), 356-369.

Chen, Y., Dou, P. Y., Rhee, S. G., Truong, C., \& Veeraraghavan, M. (2015). National culture and corporate cash holdings around the world. Journal of Banking and Finance, 50, 1-18.

Chui, A. C., \& Kwok, C. C. (2008). National culture and life insurance consumption. Journal of International Business Studies, 39(1), 88-101.

Chui, A. C., Titman, S., \& Wei, K. J. (2010). Individualism and momentum around the world. Journal of Finance, 65(1), 361-392.

Cochrane, A. B. (1981). Small business mortality rates: A review of the literature. Journal of Small Business Management, 19(4), 50-59.

Cooter, R. D., \& Schäfer, H. B. (2012). Solomon's knot: How law can end the poverty of nations. Princeton: Princeton University Press.

Da Rin, M., Nicodano, G., \& Sembenelli, A. (2006). Public policy and the creation of active venture capital markets. Journal of Public Economics, 90(8), 1699-1723.

Dai, N., Jo, H., \& Kassicieh, S. (2012). Cross-border venture capital investments in Asia: Selection and exit performance. Journal of Business Venturing, 27(6), 666-684.

De Clercq, D., Meuleman, M., \& Wright, M. (2012). A cross-country investigation of micro-angel investment activity: The roles of new business opportunities and institutions. International Business Review, 21(2), 117-129.

Dearmon, J., \& Grier, R. (2011). Trust and the accumulation of physical and human capital. European Journal of Political Economy, 27(3), 507-519.

Delhey, J., \& Newton, K. (2005). Predicting cross-national levels of social trust. Global pattern or Nordic exceptionalism? European Sociological Review, 21(4), 311-327.

Djankov, S., McLiesh, C., \& Shleifer, A. (2007). Private credit in 129 countries. Journal of Financial Economics, 84(2), 299-329.

Duffner, S., Schmid, M. M., \& Zimmermann, H. (2009). Trust and success in venture capital financing-An empirical analysis with German survey data. Kyklos, 62(1), 15-43.

Eckel, C. C., \& Wilson, R. K. (2004). Is trust a risky decision? Journal of Economic Behavior and Organization, 55(4), 447-465.

Espenlaub, S., Khurshed, A., \& Mohamed, A. (2015). Venture capital exits in domestic and crossborder investments. Journal of Banking and Finance, 53, 215-232.

Fairchild, R. (2011). An entrepreneur's choice of venture capitalist or angel-financing: A behavioral game-theoretic approach. Journal of Business Venturing, 26(3), 359-374.

Franke, R. H., Hofstede, G., \& Bond, M. H. (1991). Cultural roots of economic performance: A research note. Strategic Management Journal, 12(S1), 165-173.

Franks, J., \& Mayer, C. (2017). Evolution of ownership and control around the World: The changing face of capitalism. European Corporate Governance Institute (ECGI)_Finance Working Paper No. 503/2017.

Frijns, B., Gilbert, A., Lehnert, T., \& Tourani-Rad, A. (2013). Uncertainty avoidance, risk tolerance and corporate takeover decisions. Journal of Banking and Finance, 37(7), 2457-2471.

Fukuyama, F. (1995). Social capital and the global economy. Foreign Affairs, 74(5), 89-103.

Gallup, J. L., Mellinger, A., \& Sachs, J. D. (1999). Geography and economic development. CID Working Paper No. 1.

Giannetti, M., \& Yafeh, Y. (2012). Do cultural differences between contracting parties matter? Evidence from syndicated bank loans. Management Science, 58(2), 365-383. 
Glahe, F., \& Vohries, F. (1989). Religion, liberty and economic development: An empirical investigation. Public Choice, 62(3), 201-215.

Gompers, P., Kovner, A., Lerner, J., \& Scharfstein, D. (2008). Venture capital investment cycles: The impact of public markets. Journal of Financial Economics, 87(1), 1-23.

Gompers, P., \& Lerner, J. (2001). The venture capital revolution. Journal of Economic Perspectives, 15(2), 145-168.

Gorodnichenko, Y., \& Roland, G. (2012). Understanding the individualism-collectivism cleavage and its effects: Lessons from cultural psychology. In M. Aoki, et al. (Eds.), Institutions and comparative economic development (pp. 213-236). London: Palgrave Macmillan.

Gorodnichenko, Y., \& Roland, G. (2017). Culture, institutions and the wealth of nations. Review of Economics and Statistics, 99(3), 402-416.

Griffin, D., Guedhami, O., Kwok, C. C., Li, K., \& Shao, L. (2014). National culture, corporate governance practices, and firm performance. Working paper, University of South Carolina.

Grinblatt, M., \& Keloharju, M. (2001). How distance, language and culture influence stockholdings and trades. Journal of Finance, 56(3), 1053-1073.

Guiso, L., Sapienza, P., \& Zingales, L. (2003). People's opium? Religion and economic attitudes. Journal of Monetary Economics, 50(1), 225-282.

Guiso, L., Sapienza, P., \& Zingales, L. (2006). Does culture affect economic outcomes? Journal of Economic Perspectives, 20(2), 23-48.

Guiso, L., Sapienza, P., \& Zingales, L. (2009). Cultural biases in economic exchange? The Quarterly Journal of Economics, 124(3), 1095-1131.

Guler, I., \& Guillén, M. F. (2010). Institutions and the internationalization of US venture capital firms. Journal of International Business Studies, 41(2), 185-205.

Gupta, V., Hanges, P. J., \& Dorfman, P. (2002). Cultural clusters: Methodology and findings. Journal of World Business, 37(1), 11-15.

Gupta, V., MacMillan, I. C., \& Surie, G. (2004). Entrepreneurial leadership: Developing and measuring a cross-cultural construct. Journal of Business Venturing, 19(2), 241-260.

Hail, L., \& Leuz, C. (2006). International differences in the cost of equity capital: Do legal institutions and securities regulation matter? Journal of Accounting Research, 44(3), 485-531.

Han, S., Kang, T., Salter, S., \& Yoo, Y. K. (2010). A cross-country study on the effects of national culture on earnings management. Journal of International Business Studies, 41(1), 123-141.

Haufler, A., Norbäck, P. J., \& Persson, L. (2014). Entrepreneurial innovations and taxation. Journal of Public Economics, 113, 13-31.

Haxhi, I., \& Van Ees, H. (2010). Explaining diversity in the worldwide diffusion of codes of good governance. Journal of International Business Studies, 41(4), 710-726.

Hayward, R. D., \& Kemmelmeier, M. (2011). Weber revisited a cross-national analysis of religiosity, religious culture, and economic attitudes. Journal of Cross-Cultural Psychology, 42(8), 1406-1420.

Heine, S. J. (2008). Cultural psychology. New York: W. W. Norton \& Company.

Hicks, R., \& Tingley, D. (2012). Causal mediation analysis. The Stata Journal, 11(4), 605-619.

Hilary, G., \& Hui, K. W. (2009). Does religion matter in corporate decision making in America? Journal of Financial Economics, 93(3), 455-473.

Hofstede, G. (1980). Culture's consequences: International differences in work-related values. Beverly Hills: Sage Publications Ltd.

Hofstede, G., Hofstede, G. J., \& Minkov, M. (2010). Cultures and organizations: Software of the mind (3rd ed.). New York: McGraw-Hill.

Holderness, C. G. (2017). Culture and the ownership concentration of public corporations around the world. Journal of Corporate Finance, 44, 469-486.

Houser, D., Schunk, D., \& Winter, J. (2010). Distinguishing trust from risk: An anatomy of the investment game. Journal of Economic Behavior and Organization, 74(1), 72-81.

Huff, L., \& Kelley, L. (2003). Levels of organizational trust in individualist versus collectivist societies: A seven-nation study. Organization Science, 14(1), 81-90.

Huff, L., \& Kelley, L. (2005). Is collectivism a liability? The impact of culture on organizational trust and customer orientation: A seven-nation study. Journal of Business Research, 58(1), 96-102.

Jeng, L. A., \& Wells, P. C. (2000). The determinants of venture capital funding: Evidence across countries. Journal of Corporate Finance, 6(3), 241-289.

Jensen, M. C., \& Meckling, W. H. (1976). Theory of the firm: Managerial behavior, agency costs and ownership structure. Journal of Financial Economics, 3(4), 305-360. 
Kashima, E. S., \& Kashima, Y. (1998). Culture and language the case of cultural dimensions and personal pronoun use. Journal of Cross-Cultural Psychology, 29(3), 461-486.

Kim, E. H., \& Lu, Y. (2013). Corporate governance reforms around the world and cross-border acquisitions. Journal of Corporate Finance, 22, 236-253.

Kirkman, B. L., Lowe, K. B., \& Gibson, C. B. (2006). A quarter century of culture's consequences: A review of empirical research incorporating Hofstede's cultural values framework. Journal of International Business Studies, 37(3), 285-320.

Knack, S., \& Keefer, P. (1997). Does social capital have an economic payoff? A cross-country investigation. The Quarterly Journal of Economics, 112(4), 1251-1288.

Knight, F. H. (1921). Risk, uncertainty and profit. New York: Hart, Schaffner and Marx.

Kortum, S., \& Lerner, J. (2000). Assessing the contribution of venture capital to innovation. Rand Journal of Economics, 31(4), 674-692.

Kwok, C., \& Tadesse, S. (2006). National culture and financial systems. Journal of International Business Studies, 37(2), 227-247.

Kwon, S. W., \& Arenius, P. (2010). Nations of entrepreneurs: A social capital perspective. Journal of Business Venturing, 25(3), 315-330.

La Porta, R., Lopez-de-Silanes, F., \& Shleifer, A. (2008). The economic consequences of legal origins. Journal of Economic Literature, 46(29), 285-332.

La Porta, R., Lopez-de-Silanes, F., Shleifer, A., \& Vishny, R. W. (1997). Trust in large organizations. American Economic Review, 87(2), 333-338.

La Porta, R., Lopez-de-Silanes, F., Shleifer, A., \& Vishny, R. W. (1998). Law and finance. The Journal of Political Economy, 106(6), 1113-1155.

La Porta, R., Lopez-de-Silanes, F., Shleifer, A., \& Vishny, R. (1999). The quality of government. Journal of Law Economics and Organization, 15(1), 222-279.

La Porta, R., Lopez-de-Silanes, F., Shleifer, A., \& Vishny, R. (2000). Investor protection and corporate governance. Journal of Financial Economics, 58(1), 3-27.

Lerner, J., \& Schoar, A. (2005). Does legal enforcement affect financial transactions? The contractual channel in private equity. The Quarterly Journal of Economics, 120(1), 223-246.

Lerner, J., \& Tag, J. (2013). Institutions and venture capital. Industrial and Corporate Change, 22(1), $153-182$.

Levine, R. (2005). Finance and growth: Theory and evidence. In P. Aghion, \& S. Durlauf (Eds.), Handbook of economic growth. Amsterdam: Elsevier.

Li, K., Griffin, D., Yue, H., \& Zhao, L. (2011). National culture and capital structure decisions: Evidence from foreign joint ventures in China. Journal of International Business Studies, 42(4), 477-503.

Li, K., Griffin, D., Yue, H., \& Zhao, L. (2013). How does culture influence corporate risk-taking? Journal of Corporate Finance, 23, 1-22.

Li, Y., Vertinsky, I. B., \& Li, J. (2014). National distances, international experience, and venture capital investment performance. Journal of Business Venturing, 29(4), 471-489.

Li, Y., \& Zahra, S. A. (2012). Formal institutions, culture, and venture capital activity: A cross-country analysis. Journal of Business Venturing, 27(1), 95-111.

Licht, A. N. (2001). The mother of all path dependencies: Towards a cross-cultural theory of corporate governance systems. Delaware Journal of Corporate Law, 26(1), 147-205.

Licht, A. N., Goldschmidt, C., \& Schwartz, S. H. (2005). Culture, law, and corporate governance. International Review of Law and Economics, 25(2), 229-255.

Markman, G. D., Siegel, D. S., \& Wright, M. (2008). Research and technology commercialization. Journal of Management Studies, 45(8), 1401-1423.

Morris, M. H., Davis, D. L., \& Allen, J. W. (1994). Fostering corporate entrepreneurship: Cross-cultural comparisons of the importance of individualism versus collectivism. Journal of International Business Studies, 25(1), 65-89.

Nahata, R., Hazarika, S., \& Tandon, K. (2014). Success in global venture capital investing: Do institutional and cultural differences matter? Journal of Financial and Quantitative Analysis, 49(4), 1039-1070.

Nannestad, P. (2008). What have we learned about generalized trust, if anything? Annual Review of Political Science, 11, 413-436.

Noland, M. (2005). Religion and economic performance. World Development, 33(8), 1215-1232.

North, D. C. (1990). Institutions, institutional change and economic performance. Cambridge: Cambridge University Press.

North, D. C. (1994). Economic performance through time. American Economic Review, 84(3), 359-368. 
Popov, A., \& Roosenboom, P. (2013). Venture capital and new business creation. Journal of Banking and Finance, 37(12), 4695-4710.

Putnam, R. D., Leonardi, R., \& Nanetti, R. Y. (1993). Making democracy work: Civic traditions in Modern Italy. Princeton: Princeton University Press.

Rajan, R. G., \& Zingales, L. (1998). Financial dependence and growth. American Economic Review, $88(3), 559-586$.

Realo, A., Allik, J., \& Greenfield, B. (2008). Radius of trust social capital in relation to familism and institutional collectivism. Journal of Cross-Cultural Psychology, 39(4), 447-462.

Rieger, M. O., Wang, M., \& Hens, T. (2015). Risk preferences around the world. Management Science, 61(3), 637-648.

Roe, M. J. (2003). Political determinants of corporate governance. Oxford: Oxford University Press.

Ronen, S., \& Shenkar, O. (1985). Clustering countries on attitudinal dimensions: A review and synthesis. Academy of Management Review, 10(3), 435-454.

Sachs, J., \& Malaney, P. (2002). The economic and social burden of malaria. Nature, 415(6872), $680-685$.

Sahlman, W. A. (1990). The structure and governance of venture-capital organizations. Journal of Financial Economics, 27(2), 473-521.

Samila, S., \& Sorenson, O. (2011). Venture capital, entrepreneurship, and economic growth. Review of Economics and Statistics, 93(1), 338-349.

Sapienza, P., \& Zingales, L. (2012). A trust crisis. International Review of Finance, 12(2), 123-131.

Schwartz, S. H. (1999). A theory of cultural values and some implications for work. Applied Psychology: An International Review, 48(1), 23-47.

Schwartz, S. H. (2014). National culture as value orientations: Consequences of value differences and cultural distance, Chapter 20. In V. A. Ginsburgh, \& D. Throsby (Eds.), Handbook of the Economics of Art and Culture (Vol. 2) (pp. 547-586). Amsterdam: Elsevier.

Scott, W. R. (1995). Institutions and organizations. Foundations for organizational science. London: A Sage Publication Series.

Shane, S. (1992). Why do some societies invent more than others? Journal of Business Venturing, 7(1), $29-46$.

Shane, S. (1993). Cultural influences on national rates of innovation. Journal of Business Venturing, 8(1), $59-73$.

Shane, S. (1995). Uncertainty avoidance and the preference for innovation championing roles. Journal of International Business Studies, 26(1), 47-68.

Shao, L., Kwok, C. Y., \& Zhang, R. (2013). National culture and corporate investment. Journal of International Business Studies, 44(7), 745-763.

Siegel, J. I., Licht, A. N., \& Schwartz, S. H. (2011). Egalitarianism and international investment. Journal of Financial Economics, 102(3), 621-642.

Siegel, J. I., Licht, A. N., \& Schwartz, S. H. (2013). Egalitarianism, cultural distance, and FDI: A new approach. Organization Science, 24(4), 174-1194.

Stahl, G. K., \& Voigt, A. (2008). Do cultural differences matter in mergers and acquisitions? A tentative model and examination. Organization Science, 19(1), 160-176.

Staiger, D., Stock, J. H., \& Watson, M. W. (1997). The NAIRU, unemployment and monetary policy. Journal of Economic Perspectives, 11(1), 33-49.

Steinhardt, H. C. (2012). How is high trust in China possible? Comparing the origins of generalized trust in three Chinese societies. Political Studies, 60(2), 434-454.

Stinchcombe, A. L. (1965). Organizations and social structure. Handbook of Organizations, 44(2), $142-193$.

Stulz, R. M., \& Williamson, R. (2003). Culture, openness, and finance. Journal of Financial Economics, 70(3), 313-349.

Tarakeshwar, N., Stanton, J., \& Pargament, K. I. (2003). Religion an overlooked dimension in crosscultural psychology. Journal of Cross-Cultural Psychology, 34(4), 377-394.

Taylor, M. Z., \& Wilson, S. (2012). Does culture still matter?: The effects of individualism on national innovation rates. Journal of Business Venturing, 27(2), 234-247.

The Economist (2009). The United States of Entrepreneurs. Mar 12, 2009.

Tiessen, J. H. (1997). Individualism, collectivism, and entrepreneurship: A framework for international comparative research. Journal of Business Venturing, 12(5), 367-384.

Van Den Steen, E. (2004). Rational over-optimism (and other biases). American Economic Review, 94, 1141-1151. 
Volonté, C. (2015). Culture and corporate governance: The influence of language and religion in Switzerland. Management International Review, 55(1), 77-118.

Weber, M. (1930). The protestant ethic and the spirit of capitalism. New York: Harper Collins.

Williamson, O. E. (1975). Markets and hierarchies. New York: Free Press.

Williamson, O. E. (2000). The new institutional economics: taking stock, looking ahead. Journal of Economic Literature, 38(3), 595-613.

Wooldridge, J. M. (2010). Econometric analysis of cross section and panel data (2nd ed.). Cambridge: MIT Press.

Wright, M., Pruthi, S., \& Lockett, A. (2005). International venture capital research: From cross-country comparisons to crossing borders. International Journal of Management Reviews, 7(3), 135-165.

Yamagishi, T., Cook, K., \& Watabe, M. (1998). Uncertainty, trust, and commitment formation in the United States and Japan. American Journal of Sociology, 104(1), 165-194.

Yamagishi, T., \& Yamagishi, M. (1994). Trust and commitment in the United States and Japan. Motivation and Emotion, 18, 29-66.

Zak, P. J., \& Knack, S. (2001). Trust and growth. The Economic Journal, 111(470), 295-321.

Zhang, X., Liang, X., \& Sun, H. (2013). Individualism-collectivism, private benefits of control, and earnings management: A cross-culture comparison. Journal of Business Ethics, 114(4), 655-664.

Publisher's Note Springer Nature remains neutral with regard to jurisdictional claims in published maps and institutional affiliations. 